« Die Joden zijn bij mij per toeval gevonden » Hoe protestanten Joden redden in de omgeving van Antwerpen en Leuven (1942-1944)

\title{
Jan Maes
}

\section{CpenEdition}

Journals

Édition électronique

URL : http://journals.openedition.org/cmc/493

DOI : $10.4000 / \mathrm{cmc} .493$

ISSN : 2684-3080

Éditeur

Fondation de la Mémoire Contemporaine

Édition imprimée

Date de publication : 1 décembre 2011

Pagination : 271-317

ISSN : 1377-1256

\section{Référence électronique}

Jan Maes, « «Die Joden zijn bij mij per toeval gevonden » Hoe protestanten Joden redden in de omgeving van Antwerpen en Leuven (1942-1944) », Les Cahiers de la Mémoire Contemporaine [Online], 10 | 2011, Online op 01 décembre 2019, geraadpleegd op 13 novembre 2020. URL : http:// journals.openedition.org/cmc/493; DOI : https://doi.org/10.4000/cmc.493 


\section{« Die Joden zijn bij mij per toeval gevonden » Hoe protestanten Joden redden in de omgeving van Antwerpen en Leuven \\ (1942-1944)}

\section{Jan Maes}

In Rethinking the Holocaust schrijft Yehuda Bauer : «A historian, in my estimation, has to do two things, especially when dealing with a subject as this : one research and analyze; and two, remember that there is a story to be told, a story that relates to people's lives. So a real historian is also a person who tells (true) stories. $\aleph^{1}$

Dit artikel is een samenvatting van het onderzoek waaraan ik in het kader van mijn licenties godsdienstwetenschappen begon in april 2005. Professor Didier Pollefeyt stond mij als historicus toe om voor zijn vak Christendom en Jodendom een paper te schrijven met betrekking tot de Shoah, die nadien kon dienen als lesmateriaal voor het vak godsdienst in het secundair onderwijs ${ }^{2}$. Als kader hiervoor koos ik het in maart 1945 gepubliceerde oorlogsdagboek van Médard Schuyten, de overgrootvader van mijn echtgenote ${ }^{3}$. Het getuigenis van zijn kleindochter Julia Schuyten leek mij perfect geschikt als kernverhaal. In december 1995 schreef zij op vraag van familieleden in de Verenigde Staten een tekst, die tevens de basis vormde van een interview dat germaniste Lieve Wouters in 1999 van haar afnam ${ }^{4}$. Wouters' redactie van Julia's oorspronkelijke tekst was echter zo ingrijpend, dat ik besloot de originele versie uit 1995 als basis te nemen, deze zo grondig mogelijk te controleren, te corrigeren en aan te vullen ${ }^{5}$. Ik kwam daarbij veel interes-

1 Y. Bauer, Rethinking the Holocaust, New Haven - London, 2001, p. ix.

2 J. Maes, Daders, slachtoffers, omstanders. De vervolging van de Antwerpse joden : kiezen of niet kiezen, dat was de vraag, onuitgegeven paper Christendom en Jodendom, KULeuven, 2005.

3 M.C. Schuyten, Oorlogsdagboek, Antwerpsche nota's 1940-1944, Antwerpen, maart 1945.

${ }^{4}$ J. Schuyten, Tenminste Sylvieke, in J. De Volder en L. Wouters, Van binnen weent mijn hart. De vervolging van de Antwerpse joden. Geschiedenis en herinnering, Antwerpen, 1999, pp. 120-126.

5 E-mail van Lieve Wouters aan de auteur, 21 november 2005 ; persoonlijk archief Dora Eikelboom-Sluys (DES), J. Schuyten, Van 31 januari 1943 tot juli 16 of 171944 (Getuigenis geschreven op vraag van familieleden in de Verenigde Staten), december 1995. 


\section{Protagonisten (in vogorde waarin zij in het verhaal voorkomen)}

\section{Protestantse omstanders, redders en betaalde helpers}

Klaas Sluys en Julia Schuyten, dochter van Henri en kleindochter van Médard Schuyten ; Henri Schuyten en Margriet Oudheusden, ouders van Jeanne, Julia en René ; zoon van Médard ; Door Hendrickx en Philomena Coenen, ouders van Charles; Charles Hendrickx en Yvonne Noë, zoon van Door ; René Schuyten en Nelly Opstelten, zoon van Henri, en broer van Julia en Jeanne ; John en Lea Polderman, beste vriend van René en Nelly ; Jeanne Schuyten, oudste dochter van Henri, en zus van Julia en René ; Henri Rooze en Truus van Buuren.

\section{Slachtoffers en overlevers}

Gottfried Finkel, zoon van Markus en Laura ; Markus Finkel en Laura Einig, ouders van Gottfried en Selma ; Selma Finkel, dochter van Markus en na de oorlog echtgenote van Heinz Schindler ; Sigmund Hönig en Rosa Gross, ouders van Lily en Edith ; Lily Hönig, dochter van Sigmund, na de oorlog echtgenote van Gottfried Finkel ; Edith Hönig, verloofde van Heinz Schindler; Heinz Schindler, verloofde van Edith Hönig, na de oorlog echtgenoot van Selma Finkel ; Anna Kron-Hönig, zuster van Sigmund ; Igo Gross en Rosl Berlstein, schoonbroer en schoonzus van Sigmund Hönig en Rosa Gross ; Myriam Grosz-Reichman en haar kinderen Paula, Alexander en Annie Grosz, tante van Sylvieke; Sylvieke Reichman, nichtje van Paula, Alexander en Annie Grosz ; Dobe Grunspan-Thaler, grootmoeder (langs moederszijde) van Sylvieke Reichman ; Hersz Nadel ; Jonas Polak ; Sophia Bremer-Bremer en haar dochtertje Karin ; Josephine van Engel ; Sofie Vlessing ; Het echtpaar Wesley ; "Leo, Adèle en hun oom".

\section{Daders}

Jan Schuermans, Vlaams medewerker van de Antwerpse Sipo-SDafdeling; Louis Debra, Vlaams medewerker van de Antwerpse Sipo-SDafdeling ; Conrad Kaeding, Duits medewerker van de Antwerpse Sipo-SDafdeling ; Emile Wyndaele, Vlaams medewerker van de Antwerpse Sipo-SDafdeling; Staf Van Sintjan, VNV-oorlogsburgemeester van Boechout ; Jan Pitz, Duits medewerker van de Antwerpse Sipo-SD-afdeling ; Erich Holm, Duits hoofd van de Judenabteilung van de Antwerpse Sipo-SD ; Gustaaf De Schutter, kennis van Debra; Felix Lauterborn, Vlaams medewerker van de Antwerpse Sipo-SD-afdeling ; Emiel Janssens, Vlaams medewerker van de Antwerpse Sipo-SD-afdeling. 
sant materiaal op het spoor waarop ik de twee volgende jaren mocht verder werken ${ }^{1}$.

De historische reconstructie van de verhalen van de omstanders, slachtoffers en daders, die voorkomen in Julia's getuigenis, leidde tot de ontdekking van een nooit eerder geïdentificeerd, noch bestudeerd informeel netwerk van (minstens) vijftien Vlaamse protestantse redders en betaalde helpers in de omgeving van Antwerpen en Leuven ${ }^{2}$. $\mathrm{Zij}$ hielpen Joden uit menslievendheid, uit geloofsovertuiging, maar sommigen onder hen ook uit winstbejag. Het getuigenis van Julia Schuyten dateert van vijftig jaar na de feiten. Het werd minutieus onderzocht, aangevuld met cruciale bijkomende informatie en fouten werden verbeterd ${ }^{3}$. Maar omdat bijna alle protagonisten, inclusief $\mathrm{Ju}$ lia, reeds overleden waren op het moment dat het onderzoek werd opgestart, was - met uitzondering van Edith Hönig - bijkomende informatie uit eerste hand niet langer te verkrijgen ${ }^{4}$. Bijgevolg is dit historisch verhaal een reconstructie van ontelbare puzzelstukjes uit een groot aantal eigentijdse documenten van allerlei aard: persoonlijke dossiers in de archieven van onder andere het Auditoraat-Generaal (AG), het Ministerie van Volksgezondheid Dienst Oorlogsslachtoffers (DO) en de Dienst Vreemdelingenzaken (DV) te Brussel; de honderden brieven die Julia's broer, René Schuyten, en zijn verloofde en latere

1 J. Maes, Omstanders, slachtoffers, daders. Een verhaal van individuele keuzes en morele verantwoordelijkheid tijdens de jodenvervolging in de omgeving van Antwerpen, onuitgegeven paper voor het vak Nieuwste Tijd \& Ethiek van vrede, oorlog en internationale betrekkingen, KULeuven, 2006 ; J. Maes, « Bystanders, Victims and Perpetrators. A Descriptive Analysis of Individual Choices and Moral Responsibility in the Case of an Informal Network of Protestants Trying to Rescue Jews in the Surroundings of Antwerp and Louvain between 1942 and 1944 », onuitgegeven paper voor het vak Judaism, KULeuven, 2007. George Wilkes van Cambridge University was in 2006-2007 gastprofessor aan de KULeuven, Faculteit Godgeleerdheid. De professoren Lieve Gevers, Johan Verstraeten en George Wilkes ben ik nog altijd dankbaar voor de geboden kans.

2 Klaas en Julia Sluys-Schuyten, Henri en Margriet Schuyten-Oudheusden, René en Nelly Schuyten-Opstelten, Jeanne Schuyten, Door en Philomena Hendrickx-Coenen, Charles en Yvonne Hendrickx-Noë, Henri en Truus Rooze-Van Buuren, en John en Lea Polderman.

3 Voor informatie afkomstig uit het oorspronkelijke getuigenis van Julia Schuyten en voor voor de hand liggende correcties en aanvullingen, zoals namen, adressen en data afkomstig uit persoonlijke dossiers, volgt verder geen aparte bronvermelding.

${ }^{4}$ Persoonlijk archief Edith Sanders-Hönig (ESH), Getuigenis van Edith Hönig, 11 augustus 1995. Hiermee vroeg zij de Yad Vashemmedaille aan voor Klaas Sluys (postuum) en Julia Schuyten. Dit getuigenis werd in 2005 speciaal voor dit onderzoek vervolledigd in een reeks e-mails van Edith Hönig aan de auteur, ondanks het feit dat dit schrijfproces bij haar zeer pijnlijke herinneringen opriep. Daarvoor ben ik als auteur haar dan ook bijzonder erkentelijk. 
echtgenote Nelly Opstelten met tussenpozen aan elkaar schreven, voor en tijdens de oorlogsjaren; de jaarbalansen van 1944 en 1945 van de handelsfirma van Julia's echtgenoot, Klaas Sluys; het vonnis van Klaas Sluys... ; én latere getuigenissen van verschillende hoofdrolspelers en commentaren van nabestaanden van zowel redders, helpers als slachtoffers ${ }^{5}$. Op basis daarvan konden we de meeste in dit verhaal betrokken omstanders, slachtoffers en daders identificeren. Onduidelijkheid, onvolledigheid, gebrekkige betrouwbaarheid, subjectiviteit, (zelf)censuur en oncontroleerbaarheid van en soms zelfs tegenspraak tussen bepaalde delen van het gebruikte bronnenmateriaal maken de bevindingen en conclusies uiteraard voorlopig en onder voorbehoud. Het is mogelijk dat bepaalde verbanden over het hoofd werden gezien, bepaalde feiten verkeerd werden geïnterpreteerd of dat er in de toekomst nog nieuwe elementen worden gevonden of opduiken die een ander licht werpen op de feiten. Omdat de levenspaden van de protagonisten elkaar kruisen en gedeeltelijk overlappen, zijn vooruitblikken en terugblikken in het verhaal onvermijdelijk.

\section{De vraag om hulp}

Wanneer in mei 1940 de Duitsers België binnenvallen en de regering-Pierlot naar Groot-Brittannië vlucht, neemt het zogenaamde Comité van de Secretarissen-generaal het bestuur van het land in handen. Zolang de Duitsers hen geen zaken vragen die in tegenspraak zijn met de Belgische grondwet, zijn deze hoge ambtenaren bereid de weg van de "politiek van het minste kwaad" te bewandelen en mee te werken met de bezetter. Maar wanneer vanaf oktober 1940 de Duitsers het Comité een aantal ingrijpende administratieve hervormingen van het Belgisch systeem willen doen doorvoeren, weigeren de Secretarissengeneraal daaraan mee te werken. En het is in deze context dat ze weigeren om de eerste van een reeks anti-joodse maatregelen uit te vaardigen die ingaan tegen het gelijkheidsbeginsel zoals het beschreven

5 Persoonlijk archief Margaret Hickman-Schuyten (MHS), 530 bladzijden brieven (en enkele dagboekfragmenten) tussen René Schuyten en zijn verloofde en latere vrouw Nelly Opstelten van 14 september 1938 tot 11 mei 1948 ; DES, De balansen van 1944 en 1945 van Industrie \& Handelsmaatschappij Boechout, 31 december 1944 en 31 december 1945 ; Persoonlijk archief Marnix Sluys (MS), Feldkommandantur 520, St.L. VI nr.60/43, Vonnis van Klaas Sluys, 1 april 1943. 
staat in artikel 10 van de Belgische grondwet - alle Belgen zijn gelijk voor de wet -, waarop de Militärverwaltung beslist om deze discriminerende verordeningen maar zelf uit te vaardigen. Na het demoniseren, gebruiken de Duitsers doelbewust de in totaal 18 anti-joodse verordeningen om de Joden stap voor stap een "sociale dood" te bezorgen door hen achtereenvolgens te identificeren en lokaliseren door de Joden te definiëren en te verplichten zich te laten registreren (oktober 1940), hen te weren uit het economisch leven (oktober 1940), hen te stigmatiseren door in hun identiteitskaart het woord "JOOD-JUIF" te stempelen (juni 1941), hen te segregeren van de rest van de bevolking door hen beperkingen op te leggen met betrekking tot het openbaar leven zoals het instellen van de avondklok (augustus 1941), hen te concentreren in Antwerpen, Brussel, Luik en Charleroi (augustus 1941), hen te manipuleren via het verplicht lidmaatschap van de Vereniging van Joden in België (VJB) (november 1941), hen te isoleren door de Joodse kinderen uit het reguliere onderwijs te verwijderen (december 1941), hen te spoliëren of te beroven door middel van de "ontjoodsing" van de Belgische economie (april 1942), en hen te markeren door de verplichting de Jodenster te dragen (mei 1942) ${ }^{6}$. In juli 1942 besluit de Duitse leiding om het proces af te maken door de Joden in eerste instantie te convoceren om "te gaan werken in Duitsland", later te arresteren, de ondergedokenen te traceren, hen in de Dossinkazerne te Mechelen te verzamelen en hen vervolgens naar Auschwitz te deporteren, hen daar te selecteren en hen te liquideren of hen door slavenarbeid van honger en uitputting te laten creperen.

In de lente van 1942 vragen leden van de Gereformeerde Kerk in de Bexstraat te Antwerpen hun protestantse vriend, de Nederlandse zakenman Klaas Sluys, of hij werk heeft voor een zekere Gottfried Finkel. Hij is een negentienjarige, Russische Jood, in Wenen geboren en samen met zijn ouders en zus in 1929 vanuit Lissabon in België ingeweken $^{7}$. Hij woont in de Lange Leemstraat 413 in Antwerpen. Sluys

\footnotetext{
${ }^{6} \mathrm{~L}$. Saerens, Vreemdelingen in een wereldstad. Een geschiedenis van Antwerpen en zijn joodse bevolking (1880-1944), Tielt, 2000, pp. 499-500.

7 Dienst Vreemdelingenzaken (DV), Dossier Gottfried Finkel, A280367, Inlichtingsbulletijn betreffende vreemdelingen, 20 december 1937. Als gevolg van de inval in Rusland maakte een Omzendbrief van de Algemene Secretaris bij het Ministerie van Binnenlandse Zaken en Volksgezondheid Romsee aan de gemeentebesturen van 30 juni 1941 alle Russische vluchtelingen "vaderlandsloos". DV, Dossier Gottfried Finkel, A280367, Afschrift van een schrijven van S. aan 
zelf woont met zijn gezin in de Heuvelstraat 3 in Boechout en leidt daar een succesvolle, exportgerichte onderneming, de NV Chemical Works Boechout, die parfumoliën en smaakstoffen produceerde. Op 14 mei 1941 waren er zeven personen werkzaam ${ }^{8}$. Gottfried zal in de zaak komen werken, maar enkel 's nachts, opdat de andere werknemers hem niet kunnen zien.

In augustus 1942, wellicht kort na de eerste razzia van 15 augustus 1942, vraagt Finkel Sluys om hulp voor zowel zijn blinde moeder, Laura Einig, als voor zijn arme, in Rusland geboren vader Markus, die leurhandelaar is, zijn zuster Selma en voor zichzelf ${ }^{9}$. Iets eerder, op 15 augustus, slechts vijf dagen na zijn aankomst in België, klopt ook de in Polen geboren, maar later naar Oostenrijk uitgeweken, Joodse Sigmund Hönig - met zijn firma Helios een succesvol fabrikant van parfum en permanenttoestellen uit de Nikolaas Witsenstraat 1 te Amsterdam - aan bij zijn Boechoutse zakenrelatie met de vraag om hem, zijn vrouw Rosa Gross, hun dochters Lily en Edith, hun vriend Heinz Schindler, en zijn zuster Anna Kron-Hönig te verbergen ${ }^{10}$. Het is pas bij zijn schoonbroer Igo Gross in Schaarbeek dat hij op het lumineuze idee zou zijn gekomen om Klaas te contacteren ${ }^{11}$. Het is niets te vroeg, want in de nacht van 15 op 16 augustus worden bij de eerste grote razzia in Antwerpen 845 Joden gearresteerd en gedeporteerd ${ }^{12}$.

Nadat zij door de Duitsers waren opgeroepen voor Arbeitseinsatz in de zogenaamde werkkampen vertrekken de jongeren reeds op 27 juni 1942 in allerijl met de trein uit Amsterdam ${ }^{13}$. Zij verwijderen hun Jodensterren en hebben enkel een boodschappentas bij zich. Gelukkig

de Burgemeester van Antwerpen aangaande de registratie van Russische vluchtelingen in België, 17 februari 1942.

${ }^{8}$ DV, Dossier Klaas Sluys, A150932, Brief van de politiecommissaris van Boechout aan de bestuurder van de Openbare Veiligheid in Brussel met betrekking tot het goed gedrag en zeden van Klaas Sluys, 14 mei 1941.

9 DV, Dossier Markus Finkel, 1571278, Aanvraag voor een kaart en herkenningsteken van leurhandelaar, 28 maart 1936.

${ }^{10}$ J. Schuyten, Tenminste Sylvieke, p. 121 ; DV, Dossier Sigmund Hönig, A213361, Aanvraag van Sigmund Hönig tot het bekomen van een visum voor een paspoort, 1 september 1936; DV, Dossier Sigmund Hönig, A213361, Inlichtingsbulletijn, 11 september 1944.

${ }^{11}$ E-mail van Edith Hönig aan de auteur, 6 juli 2011.

12 W. Adriaens - E. Hautermann - I. Marquenie - P. Ramet - L. Schram - M. Steinberg, Mecheln-Auschwitz 1942-1944, deel 1, De vernietiging van de Joden en zigeuners van België, Brussel, 2009 , p. 88.

${ }^{13}$ E-mail van Edith Hönig aan de auteur, 4 juni 2005 ; 26 juni 1942 : voor Joden tot 40 jaar in Duitsland. Zie : www.kampwesterbork.nl, Tijdlijn Jodenvervolging, Polizeilicher Arbeitseinsatz. 
worden ze op de trein niet gecontroleerd. In Tilburg zouden zij zijn afgestapt en met de hulp van smokkelaars erin geslaagd de Belgische grens over te steken en de tram van Baarle-Nassau naar Antwerpen te nemen, tot bij hun tante Anna Kron-Hönig op de Kipdorpvest $11^{14}$. Wanneer enkele weken later ook nog de ouders van Heinz en nog een tante en oom van Lily en Edith de groep vervoegen, besluiten ze samen een poging te doen om naar Zwitserland te vluchten. Maar nadat ze in Frankrijk voor hun ogen Thea Hönig en Philip Landau, de tante en oom van Lily en Edith, en Samuel Schindler en Camille Körner, de ouders van Heinz, door de Duitsers zien oppakken - ongetwijfeld een traumatiserende ervaring - besluiten Lily, Edith, Heinz en Anna rechtsomkeer te maken en aan te kloppen bij hun andere oom Igo Gross en zijn vrouw Rosl in de Haechtsesteenweg 406 te Schaarbeek ${ }^{15}$.

Edith Hönig getuigt hierover : «Wij zijn met de trein naar Frankrijk vertrokken, aan de grens uitgestapt en gewoon bij een kleine plaats de grens overgegaan, zonder bagage, heel onopvallend. Vervolgens met de trein naar Parijs. We bleven daar in een klein hotel overnachten en de volgende dag ging het naar de demarcatielijn. Naar Chalon-sur-Saône. Dus met de ouders van Heinz, oom Philip, tante Thea, tante Anna, Lily, Heinz en ik. Op de brug van Chalon-sur-Saône vielen we in de handen van de Duitsers. De ouders van Heinz en oom Philip en tante Thea liepen voorop en werden gepakt. Wij, tante Anna, Lily, Heinz en ik konden ontsnappen. We hadden nog een smokkelaar bij ons. Ik weet nog dat tante Anna dollars bij zich had, verstopt in maandverband, die ze om had. We gingen dezelfde weg terug naar

\footnotetext{
${ }^{14}$ E-mails van Edith Hönig aan de auteur, 4 en 5 juli 2011.

${ }^{15}$ E-mails van Edith Hönig aan de auteur, 1 juni 2006 en 6 juli 2011. De opgepakten werden naar het transitkamp in Pithiviers gestuurd, en van daaruit naar Drancy vanwaar zij op 24 augustus 1942 met wagon 5 van het XXIII ${ }^{\mathrm{e}}$ transport naar Auschwitz werden gedeporteerd. Fébusz en Tauba Landau en Samuel en Camille Schindler hebben het niet overleefd (Mémorial de la Shoah, Catalogue des victimes, http://www.memorialdelashoah.org). Anna Hönig en haar echtgenoot Karl Kron, waren respectievelijk in november en augustus 1938 vanuit Wenen via Nederland naar België gevlucht. Karl Kron werd in mei 1940 als Oostenrijkse Rijksduitser opgepakt en geïnterneerd in het kamp te Gurs in het zuiden van Frankrijk. Op 13 of 15 mei 1942 werd hij overgeplaatst naar het werkkamp Septfonds. Op 28 augustus 1942 werd hij met het XXV transport vanuit Drancy naar Auschwitz gedeporteerd. Hij overleefde het niet (DV, Karl Kron, A393351, Inlichtingsbulletijns betreffende vreemdelingen, 10 november en 20 augustus 1938 DV, Karl Kron, A393351, Inlichtingsbulletijn inzake vreemdelingen, 10 september 1941 ; e-mail van Dorien Styven, Kazerne Dossin, aan de auteur, 5 juli 2011 ; e-mail van Laurence Schram (Kazerne Dossin) aan de auteur, 11 mei 2011).
} 
België en naar oom Igo. Puur geluk, dat we geen controle hadden. $»^{16}$ Een tijdje later komen ook Sigmund Hönig en zijn vrouw aan bij Igo Gross. Zij zijn er op 10 augustus met succes in geslaagd Nederland te ontvluchten ${ }^{17}$.

Sluys is een gereformeerde protestant met een bijzonder groot geloof en met een ongelooflijke religieuze ijver. Voór de oorlog is hij als hoofdredacteur de belangrijkste leverancier van artikels in het door hem opgerichte achtbladige VVK (Vlaanderen voor Kristus), het Veertiendaagsch Tijdschrift van en voor de Vlaamsche Jeugd. Hij groeit meer en meer uit tot een charismatische leidersfiguur in de kleine, maar in belangrijke mate mee door zijn toedoen groeiende religieuze minderheid $^{18}$. In een overwegend katholiek land als België maakt het lidmaatschap van de protestantse kerk hen tot buitenstaanders. Maar Sluys begrijpt al snel dat juist in deze "separateness" ook hun sterkte kan liggen ${ }^{19}$. Omdat de leden er meestal de voorkeur aan geven te huwen binnen de eigen geloofsgemeenschap, zijn veel families nauw verwant en goed bevriend. Het zijn dan ook net deze hechte familie- en vriendschapsbanden die Sluys aanwendt om een klein en discreet informeel netwerk van betrouwbare protestantse redders en helpers op te zetten. Als gereformeerd protestant gelooft hij immers zo sterk dat de Joden Gods uitverkoren volk zijn, dat hij hen alleen daarom al onmogelijk in de steek kan laten.

In 1941 heeft Sluys Withof gekocht, een groot huis met veel kamers. Tijdelijk brengen hij en zijn vrouw, Julia Schuyten, de Hönigs en Heinz Schindler onder op de tweede verdieping. Maar omdat Withof vlak naast zijn fabriek ligt, waar dagelijks een tiental werknemers in- en uitlopen, is het daar eigenlijk niet veilig. Sluys vindt zijn schoonouders, Henri Schuyten en Margriet Oudheusden bereid om Gottfrieds ouders voor een langere tijd in hun huis in de Speerstraat 27

\footnotetext{
16 E-mail van Edith Hönig aan de auteur, 6 juli 2011.

17 E-mail van Edith Hönig aan de auteur, 4 juli 2011.

${ }^{18} \mathrm{Na}$ de jaren na de oorlog zal hij de drijvende kracht en bezieler zijn van de School met de Bijbel en de protestantse kerk in Boechout en van het maandelijks verschijnende Het Vlaams Kerkblad, dat op meer dan 30.000 exemplaren werd verspreid.

${ }^{19}$ De term komt uit N. Tec, « Helping Behavior and Rescue During the Holocaust », in P. Hayes (ed.), Lessons and Legacies. The Meaning of the Holocaust in a Changing World, Evanston, 1991, pp. $210-224$, p. 218.
} 
op het Kiel in Antwerpen op te nemen ${ }^{20}$. Reeds voor de oorlog hebben deze bureauchef bij de Stadsdienst voor Kaaien en Hangars in de haven van Antwerpen en zijn heel stille vrouw Joodse vluchtelingen financieel gesteund ${ }^{21}$. Hij was geabonneerd op De Sjofaar, een blad voor de Zending onder de Joden ${ }^{22}$. Bijna dagelijks nodigen zij ook enkelen van hen uit voor het eten ${ }^{23}$. Door hun gulheid, gastvrijheid, dienstbaarheid en "inclusiveness" worden zij rolmodellen in altruïsme voor hun drie oudste kinderen, namelijk voor Jeanne, Julia en haar echtgenoot Klaas, en voor René24. Zijn jongste zoon van zeventien, Wim, heeft Henri in de zomer van 1942 naar een boer in Frankrijk gestuurd $^{25}$. Volgens één van hun kleindochters hadden Henri en zijn vrouw eerder al Joodse tieners verborgen, die zij echter hadden moeten wegsturen omdat zij erop stonden na zonsondergang naar buiten te gaan, na een ganse dag binnen "opgesloten" te zitten. Henri vond dat een te groot risico voor hem en zijn vrouw ${ }^{26}$.

\section{De vraag om geld}

Sluys vraagt al snel aan de welstellende Hönig om financieel bij te dragen in de kosten van de onvermogende Gottfried en Selma Finkel

\footnotetext{
20 Dit werd bevestigd en nadien verduidelijkt door de jongste zoon van Henri en Margriet. Brieven van Wim Schuyten aan de auteur, 28 oktober 2005, 1 december 2005 en 11 april 2007.

${ }^{21}$ E-mail van Jan Laplasse (SOMA) aan de auteur, 8 februari 2006.

${ }^{22}$ Archief van de Protestantse Gemeente van de Sanderusstraat te Antwerpen, Jaarbalans van de Joden Zending, 1940 \& 1941.

${ }^{23}$ Brief van Wim Schuyten aan de auteur, 11 april 2007. Het gaat hier onder andere om de uit Oostenrijk of Duitsland gevluchte Kramer. Brieven van Nelly Opstelten aan René Schuyten, 3 mei en 10 september 1939. Volgens Wim Schuyten was Kramer een van die uitgeweken joodse intellectuelen, die geen werkvergunning kregen, maar die uit een protestants fonds een stipendium kregen waardoor zij toch konden overleven. Telefonisch gesprek van Wim Schuyten met de auteur, 8 juli 2006 .

${ }^{24}$ S. Oliner en P. Oliner, The Altruistic Personality. Rescuers of Jews in Nazi Europe. What Led Ordinary Men and Women to Risk Their Lives on Behalf of Others, New York - Londen, 1988, p. 144 ; E. Fogelman, Conscience \& Courage. Rescuers of Jews during the Holocaust, New YorkLonden - Toronto - Sydney - Auckland, 1994, p. 263. En Laplasse voegde eraan toe : « Ik vond Henri Schuyten in de archieven van de Staatsveiligheid vanaf januari 1944 terug als lid van het inlichtingennet Jean. », e-mail van Jan Laplasse (SOMA) aan de auteur, 8 februari 2006.

${ }_{25}$ Telefonisch gesprek van Wim Schuyten met de auteur, 23 januari 2005.

${ }^{26}$ E-mail van Ann Lyzenga-Williams aan de auteur, 17 januari 2006. Mogelijkerwijze gaat het hier om de tweeling Benno en Siegfried Hudes $\left({ }^{\circ} 17.11 .1929\right)$. Zij doken nadien onder in een weeshuis in Schoten bij pater Petrus de Beukelaer (e-mail van John Braat aan de auteur, 14.11.2011).
} 
om (reeds in augustus 1942) onder te duiken bij de protestantse zuivelhandelaar Door Hendrickx en zijn vrouw, Philomena Coenen ${ }^{27}$. Hönig wil dat doen.

Een tijdje later zal die vraag ook worden uitgebreid tot de arme ouders van Gottfried en Selma, als ook deze noodgedwongen moeten onderduiken bij Hendrick ${ }^{28}$. Duitsers op zoek naar Joden wilden immers het huis van Henri Schuyten doorzoeken, maar deze had hen op een vrij assertieve wijze eerst om een huiszoekingsbevel gevraagd, waarop ze afdropen, wellicht geïntimideerd door deze autoriteit uitstralende man $^{29}$. Wanneer de Duitsers een tijdje later terugkomen, vissen zij echter achter het net, omdat Markus en Laura Finkel intussen in allerijl naar Hendrickx zijn overgebracht. Maar de ondergedoken Joden dienen hiervoor grote geldsommen te betalen aan de families Hendrickx. Dat blijkt ondermeer uit het getuigenis van Edith Hönig uit 1995. Maar ook uit de gemotiveerde weigering door de $2^{\text {de }}$ Aanvaardingscommissie voor Politiek Gevangenen en hun Rechthebbenden van het Ministerie van Wederopbouw van het aangevraagde statuut van politiek gevangene, en daaraan verbonden geldelijke voordelen, door de protestantse zuivelhandelaar Door Hendrickx en zijn zoon Charles, met het argument dat ze opgepakt werden voor het verbergen van Joden. Door en Charles Hendrickx hadden geen recht op het statuut van politiek gevangene " aangezien hij valt onder toepassing van art. $5,5^{\circ}$ der wet van 26/2/1947, de personen bedoelend die door de vijand aangehouden werden wegens daden gesteld uit winstbejag ${ }^{30}$.

${ }_{27}$ DV, Dossier Gottfried Finkel, A280367, Verslag van de politie van de $7^{\mathrm{e}}$ wijk in Antwerpen opgemaakt op vraag van de Openbare Veiligheid met betrekking tot de houding van Finkel tijdens de bezetting, de adressen waar in België hij van 1942 tot 1945 heeft verbleven, 16 augustus 1946; Dienst Oorlogsslachtoffers (DO), Dossier Jacobus D. Isidorus Hendrickx, Beslissing van de $2^{\text {de }}$ Aanvaardingscommissie voor Politieke Gevangenen en hun Rechthebbenden van het Ministerie van Wederopbouw inzake de aanvraag om erkend te worden als politieke gevangene, 10 mei 1951.

28 Markus was voor de oorlog leurhandelaar en in februari 1942 marktkramer. DV, Dossier Markus Finkel, 1571278.

29 Telefonisch gesprek van Peter Schuyten (oudste zoon van René Schuyten) met de auteur, 21 juli 2005 ; e-mail van Cobie Vondeling (ex-vrouw van Peter Schuyten) aan de auteur, 19 augustus 2005.

${ }^{30}$ DO, Dossier Marie-Carolus (Charles) Hendrickx, Beslissing van de $2^{\text {de }}$ Aanvaardingscommissie voor Politiek Gevangenen en hun Rechthebbenden van het Ministerie van Wederopbouw, 10 mei 1951 ; DO, Dossier Jacobus D. Isidorus (Door) Hendrickx, Beslissing van de $2^{\text {de }}$ Aanvaardingscommissie voor Politiek Gevangenen en hun Rechthebbenden van het Ministerie van Wederopbouw, 10 mei 1951. 
Charles Hendrickx greep ook naast de titel van burgerlijk weerstander omdat hij « blijkbaar met winstbejag heeft gehandeld daar deze opgespoorden hem $150 \mathrm{Fr}$. per dag per persoon betaalden, en dat hij dus niet heeft gehandeld met een vaderlandslievend oogmerk en om de strijd te voeren tegen de bezetter ${ }^{31}$. Aldus de gemotiveerde weigering van de Controlecommissie voor Burgerlijke Weerstanders van het Ministerie van Openbare Werken en van Wederopbouw. Het bedrag van $150 \mathrm{Bfr}$. is blijkbaar afkomstig uit een verklaring die Charles Hendrickx zelf aflegde tijdens het onderzoek van de Commissie ${ }^{32}$. Het lijkt ons aannemelijk dat de zoon dezelfde tarieven hanteerde als de vader. Als we zien dat in de jaarbalans van Sluys' firma eind 1944 nog een schuld open staat van 376.338,03 Bfr. op naam van Sigmund Hönig, dan hebben we toch een idee van wat het onderduiken van uiteindelijk tien personen aan Hönig heeft gekost; een bedrag dat door Klaas en Julia werd voorgeschoten, nadat Hönig ergens eind 1943 door zijn uit Amsterdam meegebrachte dollarreserves heen zat, en dat volgens de jaarbalans van eind 1945 reeds volledig door Hönig blijkt te zijn terugbetaald ${ }^{33}$. Maar de Hendrickxen zijn niet de enigen die Joden laten onderduiken in ruil voor veel geld.

René Schuyten, broer van Julia en schoonbroer van Klaas, een fysiek sterke, intelligente, moedige en ondernemende jongeman zoekt sinds zijn terugkeer uit krijgsgevangenschap wanhopig naar een inkomen dat volstaat om te kunnen trouwen met zijn verloofde Nelly Opstelten $^{34}$. Twee weken na hun verloving op 16 augustus 1939 wordt hij gemobiliseerd, nadat Hitler Polen was binnengevallen en Frankrijk en het Verenigd Koninkrijk Duitsland de oorlog hadden verklaard. Tijdens de Achttiendaagse Veldtocht, in mei 1940, vecht hij in de $5^{\mathrm{e}}$ Kompagnie van het $5^{\text {e }}$ Linieregiment, moedig tegen de snel opruk-

\footnotetext{
31 DO, Dossier Marie-Carolus (Charles) Hendrickx, Beslissing van de Controlecommissie voor Burgerlijke Weerstanders van het Ministerie van Openbare Werken en van Wederopbouw, 16 januari 1953

32 E-mail van Gert De Prins (DO) aan de auteur, 4 maart 2009.

33 DES, Jaarbalansen 1944 en 1945 van Industrie \& Handelsmaatschappij Boechout, 31 december 1944 en 31 december 1945 ; e-mail van Edith Hönig aan de auteur, 4 juli 2011.

${ }^{34}$ Dit beeld van René kunnen we goed afleiden uit een handgeschreven latere Engelse vertaling van een oorspronkelijk in het Nederlands geschreven, doch niet bewaard gebleven oorlogsdagboek en uit de honderden bladzijden tellende briefwisseling tussen René en Nelly MHS, 530 bladzijden briefwisseling (en enkele dagboekfragmenten) tussen René Schuyten en latere vrouw Nelly Opstelten van 14 september 1938 tot 11 mei 1948.
} 
kende Duitsers. Dag na dag beschrijft hij zijn verschrikkelijke ervaringen in zijn dagboek, waarin ook zijn goede protestantse vriend, John Polderman, en zijn Joodse vriend, Paul Landau, voorkomen ${ }^{35}$. Daaruit blijkt hoe goed hij reageert in crisissituaties en in momenten van acute stress. Na de overgave van het Belgisch leger, sturen de Duitsers hem uiteindelijk naar het krijgsgevangenkamp Stalag XC in NienburgWeser ${ }^{36}$. Als hij in januari 1941 uit Duitsland terugkeert, slaagt hij er pas in februari 1942 in om werk te vinden ${ }^{37}$. In de Standaardboekhandel in Antwerpen verdient hij 1200 Bfr. per maand, wat volgens hem onvoldoende is om een gezin te onderhouden, zelfs als hij dat inkomen aanvult met wat boekbinden, het opzetten van een "boekerij" en het looien van konijnenvellen, die hij verkoopt aan pelshandelaars en pelsmaaksters ${ }^{38}$. Tot hij zich plots in een brief van 28 september 1942 realiseert dat Joden schuilplaatsen nodig hebben en hij daarin een opportuniteit ziet om eindelijk te kunnen trouwen. Zelf schrijft hij hierover dat hij een idee krijgt « zooals er nog zelden in een 's menschen hoofd is opgeklommen... Wij gaan n.l. een huis huren, een groot huis met een grooten hof. Een huis met minstens 1 verdiep en met $1000 \mathrm{~m}^{2}$ land er achter. Met veel fruitbomen en genoeg plaats om een heele kinderschool in op te voeden. In dat huis gaan wij wonen... We gaan kostgangers houden !!!! Snap je ? Ja ? Flink vrouke Ben je accoord met een eenvoudig huwelijksfeest binnen een week of 6-8 ? Wil je voor vier koken in plaats van voor twee ?... Maar we zijn nog niet zo ver. Vanavond ga ik naar Klaas om met hem eens te beraadslagen, want hij moet nog een paar vrienden zoeken die mee willen werken. Hij weet er op het oogenblik nog niets van... Kans op mislukken is er haast niet, tenzij er geen liefhebbers opdagen, maar die zijn er waarschijnlijk wel... PS Als je niet wil, iets wat ik wel zou kunnen verstaan, zeg het dan direct want ik schiet in gang en ben niet te stoppen $»^{39}$.

35 MHS, René Schuyten, een handgeschreven latere vertaling van het oorlogsdagboek van soldaat in het Belgisch leger, van 9 mei 1940 tot 30 mei 1940 ; e-mail van Margaret Hickman-Schuyten aan de auteur, 30 januari 2006 .

${ }^{36}$ Archief Belgisch Leger, Personalkarte Kriegsgefangenen, René Schuyten, 1940.

37 MHS, Brief van René Schuyten aan Nelly Opstelten, 16 december 1940 ; MHS, Fragment uit het dagboek van Nelly Opstelten, januari 1941.

${ }^{38}$ MHS, Brief van René Schuyten aan Nelly Opstelten, 24 september 1942.

${ }^{39}$ MHS, Brief van René Schuyten aan Nelly Opstelten, 28 september 1942. 
De voorzichtig positieve reactie van de jongere en wat naïevere Nelly, én het antwoord daarop van René, werpen een interessant licht op wat er zo allemaal komt kijken bij het verbergen van Joden : « En nu, hoe langer ik er over nadenk, hoe onmogelijker het me lijkt. Maar kook jij die soep maar gaar en zoek het maar uit, ik ben content. Wat ik wil zeggen is : "Ja ik wil!" Ik ben erg benieuwd naar je volgende brief. Waar wil jij b.v. dat heel grote huis met minstens een verdiep mee meubileren en stoffeeren? Hoe wil jij aan dekens en lakens en verd. beddegoed voor niet twee maar voor vier persoonen geraaken? Waar halen we op voorhand al dat geld vandaan dat er zeker voor nodig is om te kunnen trouwen ? Om niet te spreken over de kwestie voedsel en kolen in de winter! We zullen met ons rantsoen ternauwernood genoeg voor één kachel hebben. En die menschen hebben geen kolenkaart. Wat doen we dan, ze bij ons laten altijd 's avonds ? Daar protesteer ik te hevigste tegen en dan wacht ik nog liever een paar jaar. Want op die manier zal ik niet gelukkig zijn als er altijd vreemden rond ons zijn. Er zijn nog zoveel dingen maar ik geloof dat we die kunnen overwinnen ? »40 René antwoordt per kerende : «Gisteren [29 september] heb ik met Klaas het voornaamste besproken, en zijn wijsheid vond het plan uitstekend en zeer goed uitvoerbaar. De hoofdpunten van het programma staan reeds op het papier en de grootste moeilijkheden zijn al opgelost. Het eenige wat er nog ontbreekt is de toestemming van jou. En dat is geen kleinigheid. Als ik me niet vergis, zul je het met beide handen aangrijpen. Verdere bijzonderheden moeten we zaterdag bespreken. Daartoe leent een brief zich heel moeilijk. Vader en moeder [Henri en Margriet Schuyten], dat is jammer, zien natuurlijk een hele hoop bezwaren. Vooral van finantieelen aard en dat is niet te verwonderen, want vooral onze uitzet zal nog met heel wat moeten aangevuld worden... $»^{41}$

\section{Het businessplan van René Schuyten}

Hoe René op het idee kwam, komen we dus niet te weten. De vier grote razzia's van augustus en september 1942 in Antwerpen zijn achter de rug en de buitenlandse Joden gaan massaal en wanhopig op zoek

${ }^{40}$ MHS, Brief van Nelly Opstelten aan René Schuyten, 29 september 1942.

${ }^{41}$ MHS, Brief van René Schuyten aan Nelly Opstelten, 30 september 1942. 
naar onderduikadressen ${ }^{42}$. Zijn ouders verbergen al een tijdje de Joodse familie Finkel, die echter een arme familie is. Maar toch is dit wellicht de reden dat hij er (bijna) zeker van is kostgangers te vinden, die dat kostgeld wel kunnen en willen betalen. René schiet in gang, gaat huizen bekijken en stelt een echt businessplan op. Het geld om de nodige aankopen te kunnen doen, komt van Henri Schuyten, die eerder Julia (en Klaas) financieel had geholpen bij hun zaak. Ook nu komt hij met geld over de brug. "Ons inkomen zal zoo ongeveer 10.000 frank per maand bedragen naar mijn schatting. Eerder meer als minder. Denk maar eens goed na of gij daarmee kunt rondkomen. Van vader krijgen wij waarschijnlijk 10.000 frank voor het noodige bij te koopen. Daarmee kunnen we wel het allernoodzakelijkste ons aanschaffen. Van Jeanne krijgen we haar cosy-corner alvast in leen tot we hem niet meer noodig hebben of tot ze hem zelf noodig heeft. Ook een wollen deken voor ons beddekijn krijgen we heel waarschijnlijk van haar. Dus dat begint er al een beetje op te lijken. Van die 10.000 frank moeten we dan echter ook onze kolen en aardappelen betalen. Maar dat is niet zoo erg want dat sparen we dan uit op ons inkomen en kunnen we later dan voor iets anders gebruiken. Met dat al zullen we waarschijnlijk genoeg over houden om ons tijdig een nieuw kleedje een frakske en ook eens iets nieuws in ons huishouden te koopen. Mijn vellen doe ik verder voort en aan mijn boeken denk ik eerst goed te beginnen als wij eenmaal geïnstalleerd zijn. Volgens mij komt alles dus op zijn pootjes terecht eenmaal misschien onze verdiensten inkrimpen. $»^{43}$ In zijn brief geeft hij ook nog een lijstje van zaken die ze volgens hem nog zullen moeten bijkopen.

Twee dagen later lijkt René al een idee te hebben van wie zijn (Joodse ?) kostgangers zullen zijn en zijn er blijkbaar al een aantal afspraken gemaakt. Klaarblijkelijk was Sigmund Hönig welstellend genoeg om 12.000 Bfr. per maand op te hoesten, en dit moet René blijkbaar al geweten hebben wanneer hij in een heel belangrijke brief van 1 oktober 1942 Nelly ervan probeert te overtuigen dat hij alles goed heeft uitgedacht. Dat valt tussen de regels te lezen. Deze geeft tevens een goed inzicht in de praktische problemen waarmee wie Joden wou laten onderduiken geconfronteerd werd. Deze brief is tevens een

${ }^{42}$ I. Meinen, De Shoah in België, Antwerpen - Amsterdam, 2011, p. 64.

${ }^{43}$ MHS, Brief van René Schuyten aan Nelly Opstelten, 30 september 1942. 
vrij uniek document, wegens het volledige businessplan en de nauwkeurige berekening van alle inkomsten en uitgaven en het antwoord op de bedenkingen van Nelly : « Het plan gaat door en elken dag komt er meer en meer licht in de duisternis. Ik zal een voor een je bezwaren eens trachten te weerleggen.

1. Waarmee meubileren we ons huis ? Antwoord: met onze eigen meubelen voor ons zelf en met de meubelen die onze gasten zullen meebrengen. Dat is al in orde.

2. Waar halen we dekens en lakens vandaan niet alleen voor ons maar voor vijf personen? Antwoord: Met hetgeen wij koopen van de 10.000 frank die we van vader meekrijgen en voor de anderen : zie hierboven.

3. Waar halen we geld om te kunnen trouwen? Antwoord: Eveneens van die 10.000 frank.

4. Hoe komen we aan etensvoorraad? Antwoord: Met mijn rantsoen voor de eerste tijd, en met hetgeen we gaan bijkoopen voor den winter op de $z$ [warte] $m$ [arkt].

5. Hoe komen we aan kolen? Antwoord: Ik heb reeds 1500 Kilo bruinkool besteld aan 550 frank de ton. Ik kan turf krijgen aan 450 frank de ton. En we moeten zorgen dat jouw en mijn rantsoen kolen van de Speerstraat naar onze nieuwe woning komt. Daarbij het nog te ontvangen rantsoen.

6. Moeten die menschen altijd bij ons zitten ? Antwoord : Die menschen blijven waar ze zijn. nl. boven met uitzondering als wij eens zin hebben om niet alleen te zijn.

Zoo voorlopig is dat genoeg.

Gisteren was ik bij Klaas. Ons inkomen zal bedragen : 12000 frank kostgeld. 1200 frank pree [voor zijn werk bij de Standaardboekhandel] en 800 frank vellen samen 14000 frank. Daarvan zullen we gebruiken :

2400 frank voor 8 kilo boter aan 300 frank

2100 frank voor zeven broodkaarten aan 300 frank

600 frank voor twee broodkaarten aan 300 frank voor onszelf

200 frank voor 4 vleeschkaarten aan 50 frank

300 frank voor de prijs van het vleesch

960 frank voor 120 patateen [sic] aan 8 frank per kilo

300 frank voor een kilo vet 
340 frank voor vier kilo suiker aan 85 frank

300 frank voor 12 potten jam aan 35 frank

500 frank voor groenten

200 frank voor 30 melkzegels

450 frank voor fruit aan 15 frank per dag

150 frank voor 1 kilo zeep

75 frank voor licht

350 frank voor verwarming (gerekend aan 12 maanden per jaar) $»^{44}$.

9225 frank voor alles tesamen, maar dan heeft René nog niet de huur van het huis meegerekend. Op 5 oktober gaat hij kijken naar een alleenstaande villa in Edeghem, waar ze 450 frank per maand voor vragen.

René werkt als gek om alles zo snel mogelijk voor elkaar te krijgen. Op 2 oktober schrijft hij : « En ik heb nu ineens genoeg ondernemingsgeest gekregen om den oorlog op mijn eentje te kunnen winnen... De huizen zijn zeer zeer zeer zeer schaars en het grootste pak zal van mijn hart vallen als ik er eentje heb. »45 Op 5 oktober schrijft René : «Liefste ik VERDRINK IN HET WERK EN HEB GEEN TIJD, zelf niet voor mijn schat van een vrouke. $»^{46}$ Op 19 oktober doen ze hun ondertrouw $^{47}$.

Op 20 november, drie dagen na het huwelijk van René en Nelly, worden Sigmund Hönig, zijn vrouw Rosa en ook hun dochter Lily overgebracht naar het huis dat het jonge echtpaar huurt in de Leopold III-lei 11 te Edegem ${ }^{48}$. Later zal Anna Kron-Hönig overkomen van Door Hendrickx en de plaats innemen van Lily, die op haar beurt naar Door Hendrickx wordt overgebracht zodat alle jongeren bijeen zijn ${ }^{49}$. De Hönigs blijven daar wellicht tot 31 januari 1943, de dag dat er een inval is bij Sluys (zie verder). Na de arrestatie van Sluys, doet het gerucht de ronde dat ze ook bij René en Nelly zullen binnenvallen.

${ }^{44}$ MHS, Brief van René Schuyten aan Nelly Opstelten, 10 oktober 1942.

${ }^{45}$ MHS, Brief van René Schuyten aan Nelly Opstelten, 2 oktober 1942.

${ }^{46}$ MHS, Brief van René Schuyten aan Nelly Opstelten, 5 oktober 1942.

47 DV, Dossier Opstelten, Nelly, A17360, Formulier van ondertrouw van Nelly en René, 19 oktober 1942

${ }^{48}$ Nelly schrijft deze datum in de kantlijn van de tekst van Julia Schuyten: e-mail van Margaret Hickman-Schuyten aan de auteur, 6 februari 2006 ; MHS, Een gedrukte huwelijksaankondiging van 10 november 1942 .

${ }^{49}$ E-mail van Edith Hönig aan de auteur, 6 juli 2011. 
Eduard Hendrickx, jongste zoon van Door Hendrickx, brengt Nelly hiervan op de hoogte, op een moment dat René niet thuis is. Naar eigen zeggen belt zij René's vroegere wapenbroeder en beste vriend, de protestant John Polderman op met de vraag of hij en zijn vrouw Lea, het echtpaar Hönig voor enkele dagen kunnen opnemen. Polderman werkte in 1942 ook in de zaak van Sluys ${ }^{50}$. Het echtpaar stemt daar blijkbaar mee in en Nelly beschrijft dan veel later hoe zij met de hulp van Eduard, die haar waarschuwt als er gevaar dreigt, deze mensen om één uur 's middags te voet van Edegem naar Boechout heeft gebracht. Het echtpaar Polderman heeft geen geld gekregen voor de korte tijd dat de Hönigs bij hen verbleven ${ }^{51}$. Enkele dagen later kunnen ook zij terecht bij Door Hendrickx in Edegem ${ }^{52}$.

\section{De groothartigheid van Klaas Sluys en Julia Schuyten}

De jaarbalans van de zaak van Sluys toont dat hij reeds eind 1944 ongeveer een half miljoen frank had uitgegeven aan eten, huur voor woningen en appartementen voor de Joden die bij hem hebben aangeklopt en aan de "risicopremies" die de Hendrickxen aan de Joden vroegen. Sluys had voldoende financiële middelen om dat geld voor te schieten. "Im Jahre 1942 hat er seine Firma in eine Aktiengesellschaft umgewandelt. An dem Kapital von 1 Million bfrs. sind wesentlicht nur er und seine Ehefrau beteiligt. [...] Er [...] verdient nach seiner Angabe monatlich ca. 15.000 bfrs. ${ }^{53}$ De enige die na de oorlog in staat was zijn deel in de gemaakte onkosten terug te betalen, was Sigmund Hönig ${ }^{54}$.

Sluys schiet ook geld voor om een schuilplaats te huren voor de reeds sinds 1925 vanuit Roemenië in België ingeweken Myriam GroszReichman en haar drie kinderen, de 16-jarige Paula, de 14-jarige Alexander en de 13-jarige Annie, wanneer ook zij ergens tussen 11 september en 20 oktober 1942 Klaas om hulp vraagt ${ }^{55}$. Myriams man, de

\footnotetext{
${ }^{50}$ MHS, Brief van René Schuyten aan Nelly Opstelten, 10 oktober 1942.

51 E-mail van Edith Hönig aan de auteur, 5 juli 2011.

${ }^{52}$ MHS, Handgeschreven presentatie van Nelly Opstelten voor Paul Hickman, haar kleinzoon, zijn Duitse les, 12 april 1994 ; e-mail van Edith Hönig aan de auteur, 9 november 2005.

${ }_{53}$ MS, Feldkommandantur 520, St.L. VI nr.60/43, Vonnis van Klaas Sluys, 1 april 1943.

54 DES, Jaarbalansen 1944 en 1945 van Industrie \& Handelsmaatschappij Boechout, 31 december 1944 en 31 december 1945.

55 DV, Dossier Zoltan Grosz, 1365384, Inlichtingsbulletijn betreffende vreemdelingen, 27 september 1938 ; DV, Dossier Heinz Schindler, 2014544, Rapport van de politie van Sint-Joost-
} 
diamantsnijder Zoltan Grosz, is al op 4 september opgepakt ${ }^{56}$. Het is goed mogelijk dat Gottfried Finkel, die net als de familie Grosz ook in een appartement woonde in de Lange Leemstraat 413 te Antwerpen, Myriam heeft verteld over de hulpvaardige Sluys ${ }^{57}$. Myriam brengt hoogstwaarschijnlijk ook haar nog geen drie jaar oud achternichtje Sylvieke Reichman mee, van wie de ouders bij de grote razzia van 11 september afzonderlijk van elkaar zijn opgepakt. Eerst wordt haar moeder, Itta Grunspan, opgepakt, wellicht ergens in de buurt van haar woning op de Plantin en Moretuslei 86 te Antwerpen, en enkele uren later haar vader, de diamanthandelaar Benoît Reichman, samen met drie van zijn broers ${ }^{58}$. Ook Sylviekes grootmoeder langs moederszijde, Dobe Grunspan-Thaler, komt bij Sluys terecht ${ }^{59}$. Toen men op 29 september 1942 bij deze laatste binnenvalt, is zij zo ziek dat zij ervan overtuigd zijn dat zij het niet lang meer zal maken en zij haar in bed achterlaten. Haar echtgenoot, de diamantmakelaar Joel Grunspan, een dochter en schoonzoon worden echter wel meegenomen ${ }^{60}$. Dobe herstelt echter. Het is mogelijk dat zij pas enkele weken na Myriam Grosz bij Sluys terecht komt. Sylvieke is op 11 september niet bij een van haar ouders en op 29 september ook niet bij haar grootmoeder. Anders was ze zeker mee opgepakt. Mogelijk is ze op 11 september toevallig bij haar tante Myriam en op 29 september reeds op Withof, waar Julia voor haar zorgt als voor een eigen kind.

Geconfronteerd met deze nieuwe vraag om hulp, besluit Sluys om plaats voor hen te maken door op 20 oktober Heinz Schindler, Edith

ten-Noode met betrekking tot de houding van Schindler tijdens de bezetting, de adressen waar hij in België van 1942 tot 1944 heeft verbleven, 10 november 1944.

${ }^{56}$ E-mail van Laurence Schram (Kazerne Dossin) aan de auteur, 14 april 2005. Hij werd op 12 september met het Judentransport IX naar Auschwitz gedeporteerd. Hij overleeft het niet. W. Adriaens - E. Hautermann - I. Marquenie - P. Ramet - L. Schram - M. Steinberg, op. cit., deel 4, Namenlijst van de gedeporteerden, Brussel, 2009, p. 144.

57 DV, Dossier Zoltan Grosz, 1365384, Inlichtingsbulletijn betreffende vreemdelingen, 27 september 1938.

${ }^{58}$ DV, Dossier Benjamin Reichman, 1379678 ; W. Adriaens - E. Hautermann - I. Marquenie - P Ramet - L. Schram - M. Steinberg, op. cit., deel 4, pp. 307-308. Zij worden allen op 15 september 1942 naar Auschwitz gedeporteerd met Judentransport X. Geen van hen overleefde het.

${ }^{59}$ J. Schuyten, op.cit., p. 122. DES, De balans van 1944 van Industrie \& Handelsmaatschappij Boechout, 31 december 1944.

${ }^{60}$ Op 10 oktober worden zij gedeporteerd met Judentransport XII. Enkel de schoonzoon, Eisig Safir, overleefde Auschwitz. W. Adriaens - E. Hautermann - I. Marquenie - P. Ramet - L. Schram - M. Steinberg, op. cit., pp. 147 en 330. 
Hönig en Anna Kron-Hönig naar Door Hendrickx over te brengen ${ }^{61}$. Edith, die zich het verblijf op Withof herinnert « als één van de gelukkigste perioden van mijn totale onderduiktijd », wordt net als de anderen van de reden van deze transfer in het ongewisse gelaten ${ }^{62}$. « Wij beschikten over een eigen badkamer; en zelfs meen ik mij een kleine zijkamer te herinneren waar we naar hartelust naar radiomuziek mochten luisteren. Deze muziek bestond voor een groot deel uit Duitse amusementsmuziek, maar op onze leeftijd en onder deze omstandigheden was elke muziek welkom. Zodra het donker werd, werden we "gelucht", en ik herinner me de avondwandelingen in de prachtige tuin. Tot mijn schande moet ik bekennen, dat er een groot aantal perziken vanaf de toen in bloei staande bomen aan onze gulzigheid ten prooi vielen - iets, dat naar ik hoop, ons na zoveel jaren door de familie vergeven is. Onze maaltijden waren geregeld; zij vonden beneden in de gemeenschappelijke eetkamer plaats. Bijgebleven zijn mij ook de gebeden en dankzeggingen voor en na de maaltijden. Zeer zeker waren de maaltijden juist toen gezegend! Groot was onze teleurstelling, toen gepaard gaande met afkeuring vanwege onbegrip, toen ons op zekere dag werd meegedeeld dat wij naar elders moesten vertrekken. Zeker beseften we toen noch welk gevaar de familie Sluys liep om ons te verbergen noch dat we plaats moesten maken voor andere Joodse vluchtelingen die, evenals wij tevoren, zonder onderkomen waren en bij de familie Sluys waren aangeland. ${ }^{63}$

Myriam en haar kinderen verblijven eerst in september nog twee weken op Withof, worden nadien overgebracht naar een woning die Sluys voor hen heeft kunnen huren op de Hovesteenweg te Boechout, tot zij op 15 januari 1943 daar weg moeten en dienen terug te keren naar Withof ${ }^{64}$. Tegen 30 januari was hij er blijkbaar weer in geslaagd om een huis te huren om de Joden in onder te brengen. Ze moesten alleen nog overgebracht worden van Withof naar die "nieuwe" ver-

${ }^{61}$ DV, Dossier Heinz Schindler, 2014544, Rapport van de politie van Sint-Joost-ten-Noode met betrekking tot de houding van Schindler tijdens de bezetting, de adressen waar in België hij van 1942 tot 1945 heeft verbleven, 10 november 1944.

${ }^{62}$ ESH, Getuigenis van Edith Hönig, 11 augustus 1995.

${ }^{63}$ Ibid.

${ }^{64}$ MS, Feldkommandantur 520, St.L. VI nr.60/43, Vonnis van Klaas Sluys, 1 april 1943. 
blijfplaats ${ }^{65}$. Er rekening mee houdend dat Sluys tijdens zijn ondervraging door de Sipo-SD niet de gehele waarheid heeft verteld, geeft de volgende passage uit het vonnis dat Kriegsgerichtsrat Dr. Baudish van de Feldkommandantur 520 velt over Sluys ons toch enig inzicht in de gang van zaken, vooral omdat uit hetzelfde vonnis blijkt dat de ondervragers de verklaringen van Sluys ook getoetst hebben aan de verklaringen die Myriam Grosz en haar kinderen hebben afgelegd bij hun ondervragingen : "Während der ganzen Zeit versorgte er die Familie mit Geld und Lebensmitteln. Die letzteren beschaffte er teils aus Rationierungsmarken, die ihm angeblich von 3 . Seite durch die Post zugesandt wurden, und teils auf dem schwarzen Markt. Insgesamt gab der Angeklagte der Familie Gross [sic] ungefähr 16.000 Frank. Eine Quittung liess er sich nicht über diese Beträge geben. [...] Die Frau Gross [sic] soll ihm versprochen haben, das Geld nach Beendigung des Krieges zurückzuzahlen. $^{66}$ In de jaarbalans van 1944 van Klaas' zaak staat er nog een uitstaande schuld van 31.203,60 Bfr. op naam van « Mme Grosz - in Ballingschap ${ }^{67}$. In de jaarbalans van 1945 vinden we deze schuld niet meer terug ${ }^{68}$. Wellicht was het Klaas inmiddels duidelijk geworden dat Myriam, noch haar kinderen ooit nog zouden terugkeren. Voor Dobe Thaler vindt Klaas volgens Julia een onderkomen in Hove, waar zij tot op de dag van de bevrijding blijft : « Zo kon ik regelmatig Silvieke (zo heette dat kleintje) een halve dag bij haar grootmoeder brengen en later weer ophalen. $»^{69}$

Julia's oudste zuster, Jeanne, is hoofdverpleegster in het Stuyvenbergziekenhuis te Antwerpen. $\mathrm{Zij}$ heeft haar eigen kamertje in het ziekenhuis en enkel op haar vrije dagen gaat ze naar haar ouders. Mogelijk vanuit haar concerned professionalism als verpleegster, voor wie helpen een natuurlijke en logische uitbreiding is van haar opleiding en dagelijks werk, verbergt zij al voor 15 augustus 1942 de Poolse, in maart 1939 uit Duitsland gevluchte, Joodse werkloze garnierder, Hersz

${ }^{65}$ AG, Dossier Louis Debra, Getuigenis van Klaas Sluys op de openbare zitting van het proces van Debra, 8 december 1949.

${ }^{66}$ Ibid.

${ }^{67}$ DES, De balans van 1944 van Industrie \& Handelsmaatschappij Boechout, 31 december 1944.

${ }^{68}$ DES, De balans van 1945 van Industrie \& Handelsmaatschappij Boechout, 31 december 1945.

${ }^{69}$ DES, J. Schuyten, Van 31 januari 1943 tot juli 16 of 171944 (Getuigenis geschreven op vraag van familieleden in de Verenigde Staten), december 1995. Tot op heden konden wij het juiste adres niet achterhalen. 
Nadel $^{70}$. Hij heeft zich in het ziekenhuis laten opnemen voor een niet acute appendicitis in de hoop niet te moeten gaan meewerken aan de bouw van de Atlantikwall in Noord-Frankrijk, zoals vele andere Joodse mannen ${ }^{71}$. Terwijl hij in het ziekenhuis ligt, worden in de nacht van 15 op 16 augustus 1942 tijdens de eerste grote razzia in Antwerpen zijn vrouw en zijn jongste, 17 -jarige zoon thuis, in de Provinciestraat 125 opgepakt ${ }^{72}$. Zijn oudste zoon, Max, is op dat ogenblik in een joodse tuinbouwschool in Bomal en duikt nadien onder ${ }^{73}$. Nadat hij hersteld is, kan Hersz niet meer terug naar huis. Wellicht met medeweten en mogelijk ook met de hulp van een dokter en enkele van haar ondergeschikte verpleegsters, slaagt Jeanne er in om hem in het ziekenhuis te houden en hem in een kast te verbergen telkens er gevaar dreigt. Als men hem komt oppakken en zij naar hem informeren, vertellen Jeanne en haar collega's dat hij zonder hun medeweten en duidelijk ingaand tegen hun medisch advies op een bepaald ogenblik het ziekenhuis blijkt te hebben verlaten ${ }^{74}$. Vanaf augustus 1942 werden zieke Joden in Antwerpen enkel nog toegelaten en dan nog voor de kortst mogelijk tijd in een gesloten afdeling van het Antwerpse Sint-Erasmusziekenhuis, waar geregeld Joden die gezond genoeg waren, werden geselecteerd om te worden gedeporteerd ${ }^{75}$. «Voor de stationaire behandeling van Joden is een gesloten afdeling in het Sint-Erasmus Gasthuis te Borgerhout voorbehouden geworden. Het is voortaan [enkele uitzon-

${ }^{70}$ De term concerned professionalism is afkomstig van psychotherapeute en sociaal psychologe Eva Fogelman. E. Fogelman, op. cit., pp. 159, 292.

${ }^{71}$ Gesprek van Hanna Gnazik (schoondochter van Herman Nadel) met de auteur, 8 november 2010

72 E-mail van Laurence Schram (Kazerne Dossin) aan de auteur, 29 april 2005 ; DV, Dossier Manfred Nadel, A375136, Vernieuwing van Manfreds witte identiteitskaart, 24 juli 1942; op 18 augustus worden Estera Nadel-Neumann en Manfred met Judentransport IV naar Auschwitz gedeporteerd. Zij overleven het niet. W. Adriaens - E. Hautermann - I. Marquenie - P. Ramet L. Schram - M. Steinberg, op. cit., deel 4, pp. 275 en 280.

${ }^{73}$ DV, Dossier Max Nadel, A375136, Inschrijving van Max in het vreemdelingregister van Bomal, 3 juli 1942; Max Nadel huwt kort na de oorlog Hanna Gnazik en samen vertrekken zij naar Palestina. Hij overlijdt er op 19 februari 2003. Max heeft jammer genoeg nooit geweten dat er nog mensen zijn geweest die zijn vader hebben proberen te redden. Hij dacht dat de Gestapo zijn vader in het ziekenhuis was komen oppakken. Telefonisch gesprek van Hanna Gnazik met de auteur, 24 oktober 2005. Over de tuinbouwschool van Bomal, zie : B. Dickschen, « La ferme-école juive de La Ramée durant l'Occupation (avril 1941-août 1942) », in Bijdragen tot de Eigentijdse Herinnering, nr 6, 2005, pp. 79-133.

${ }^{74}$ E-mail van Ann Lyzenga-Williams aan de auteur, 16 januari 2006.

${ }^{75}$ E. Schmidt, Geschiedenis van de Joden in Antwerpen in word en beeld, Antwerpen, 1994, p. 202. 
deringen niet te na gesproken] aan alle stedelyke en private gasthuizen en Sanatoria verboden Joden op te nemen of ambulant te behandelen. ${ }^{76}$ Tegen midden januari 1943 wordt het in het Stuyvenbergziekenhuis zo gevaarlijk om nog langer een Jood te verbergen, dat Jeanne haar zus Julia vraagt om Nadel bij haar onder te brengen.

\section{De inval bij Sluys}

In de nacht van 30 op 31 januari 1943 stoppen twee wagens met daarin zeven leden van de Antwerpse Sipo-SD ${ }^{77}$. Eén van hen, Jan Schuermans, verklaart na de oorlog in het kader van het proces tegen Louis Debra : "Ik herinner me inderdaad de aanhouding van den $\mathrm{hr}$ SLUIS te Boechout in Januari 1943. Ik was daar inderdaad bij te samen met Kaeding (overleden) - DE BRA - ik meen ook Wyndaele, Emiel en anderen die ik me niet meer herinner. In elk geval was DE BRA er inderdaad bij. Hij heeft mede de huiszoeking gedaan. Vermoedelijk was DE BRA gewapend met een revolver. Ik meen dat toevallig er ook Joden werden aangetroffen. Er was 'n schrijven toegekomen waarin vermeld werd dat SLUIS een geheime drukkerij had. Ik weet niet of de burgemeester Van Sintjan mede naar de woning is gegaan. $^{78} \mathrm{Op}$ het proces van Debra bevestigt Sluys : « Diegene die de huiszoeking gedaan hebben noemde elkaar met de naam en zo heb ik vernomen dat WEYNDAELE en SCHUERMANS erbij waren. " $^{79}$ De anonieme tip dat Sluys naar de Britse radio luisterde en dat hij een geheime drukkerij had, illegale pamfletten drukte en deze ook verspreidde, verklaart waarom de Duitse SS-Scharführer en Sachbearbeiter Conrad Kaeding, hoofd van de Abteilung IV $C$ voor Auskünfte, Schutzhaft, Presse und Schrifttum, Emigranten de leiding had en waarom hij vergezeld was van de uit de Oostkantons afkomstige, sinds 1930

${ }^{76}$ AG, Dossier Felix Lauterborn, Vertaling van een brief van Oberstabarzt Schwarz aan Dr Grauls, provinciegouverneur van Antwerpen, betreffende de verpleging van Joden in de Gasthuizen, 10 augustus 1942.

${ }_{77}$ AG, Dossier Louis Debra, Getuigenis van Klaas Sluys op de openbare zitting van het proces van Debra, 8 december 1949.

78 AG, Dossier Louis Debra, Proces-verbaal nr 1504 der Rijkswacht van Mortsel met de verklaring van Jan Schuermans over de aanhouding van Sluis en Joden te Boechout, 31 oktober 1947.

${ }^{79}$ AG, Dossier Louis Debra, Getuigenis van Klaas Sluys op de openbare zitting van het proces van Debra, 8 december 1949. 
in Lier wonende en als zwembaduitbater werkende, 37-jarige, Duitstalige Belg, de brutale SS-Staffelmann en Dolmetscher Jan Pitz, hoofd van de Abteilung IV Al voor Gegner und Abwehr: Kommunismus, Marxismus, Feindpropaganda ${ }^{80}$. Zij werden geassisteerd door Vlaamse Sipo-SD-leden die ook niet werkten voor de Judenabteilung: de 26jarige, hevig anti-communistische, eind 1941 zelf voor een job bij de SD solliciterende Hilfspolizeibeamte Emile "Willy" Wyndaele uit Boechout, hoofd van de Ermittlungsdienst en regelmatig samenwerkend met de Abteilung IV $A$, de eveneens vrijwillig tot de SD toegetreden, zeer brutale, 19-jarige, uit Lier afkomstige Hilfspolizeibeamte en Dolmetscher Jan Schuermans, assistent bij de Abteilung IV D2 voor Widerstand, Geiseln, Sühneleistungen, Ausweisungen, Abschiebungen, Schutzdienst, de eveneens erg brutale, zeer antisemitische, 36-jarige opportunist, Dolmetscher Louis Debra uit Mortsel en « verders waren er nog twee Vlamingen bij, die ik hun naam niet heb hooren vernoemen » en waarvan de identiteit ook niet uit een andere bron kon worden achterhaald $^{81}$. Deze zeven werden vergezeld door Staf Van Sintjan, de VNV-oorlogsburgemeester van Boechout. Omdat ze het huis van Sluys niet kunnen vinden, besluiten Kaeding, Debra en Schuermans naar het huis van de met de Duitsers collaborerende burgemeester te rijden. Hij moet tonen waar Withof ligt ${ }^{82}$. Het is opmerkelijk dat Klaas na de oorlog op het proces van Debra, Van Sintjan in bescherming neemt : « De burgemeester was volgens zijn verklaring opgeëist, hij volgde de zaak, maar was niet actief, hij beschermde mijn belangen. ${ }^{83}$ Drie Sipo-SD-leden kammen het hele huis uit, terwijl de vier anderen de

\footnotetext{
${ }^{80}$ AG, Dossier Louis Debra, Proces-verbaal van een verklaring Debra met betrekking tot de inval bij Sluys, 7 november 1947 ; AG, Dossier Louis Debra, Proces-verbaal van het verhoor van Jan Schuermans met betrekking tot de aanhouding van Sluys inzake het onderzoek tegen Debra, 28 oktober 1947 ; AG, Dossier Louis Debra, Proces-verbaal van de verklaring van Klaas Sluys met betrekking tot de betrokkenheid van Van Sintjan bij de inval inzake het onderzoek tegen Van Sintjan, 17 september 1945; AG, Dossier Louis Debra, Proces-verbaal van het getuigenis van Klaas Sluys en het antwoord daarop van Debra op de openbare zitting van het proces van Debra, 8 december 1949.

${ }^{81}$ AG, Dossier Gustaaf Van Sintjan, Proces-verbaal van de verklaring van Klaas Sluys ter voorbereiding van het proces van Van Sintjan, 17 september 1945: G, Dossier Louis Debra, Getuigenis van Klaas Sluys op de openbare zitting van het proces van Debra, 8 december 1949. ${ }^{82}$ AG, Dossier Louis Debra, Proces-verbaal van een verklaring Debra met betrekking tot de inval bij Sluys, 7 november 1947; AG, Dossier Louis Debra, Getuigenis van Klaas Sluys op de openbare zitting van het proces van Debra, 8 december 1949.

${ }^{83}$ Ibid.
} 
fabriek doorzoeken ${ }^{84}$. «Op zeker ogenblik zag ik DEBRA die een schuif wilde forceren, ik zegde hem, dat hij het recht niet had dit te doen, hij zegde mij daarop, dat hij het recht had mij neer te schieten. $»^{85}$ Debra geeft dat tijdens zijn proces ook toe : «Ik geef toe getuige bars te hebben toegesproken, daar men mij gezegd had dat hij communistische druksel vervaardigde en ik ben anti-communist. $»^{86}$ Eén van hen stelt vast dat de radio in het bureau van Klaas staat afgesteld op de $\mathrm{BBC}$, en in de villa ontdekken zij Hersz Nadel en Myriam Grosz en haar drie kinderen. « Die Joden zijn bij mij per toeval gevonden, ik wilde ze naar een huis dat ik gehuurd had overbrengen. $\aleph^{87}$ De gebedssjaal van Zoltan Grosz, die Alex had "geërfd", bleef achter bij de familie Sluys ${ }^{88}$.

Julia getuigt : " Alle kinderen, Dora 4 jaar, Jan nog geen 3 jaar en Herman bijna 2 jaar en Silvieke 3 jaar sliepen en werden niet wakker. Ook omdat ik die mannen aldoor maar maande stil te zijn voor de kinderen. (Wonder, want die Duitsers [sic] met hun zware laarzen liepen het hele huis door !) Eén van die mannen vroeg mij hoeveel kinderen ik had en ik zei 4. Ik had er zelf maar 3, maar had ik dat gezegd dan hadden ze Silvieke meegenomen. Ik had een dienstmeisje en die hadden ze het ook gevraagd en die had ook gezegd dat we 4 kinderen hadden ${ }^{89}$. En Silvieke, met haar zwarte krullekopje, zat gelukkig diep onder de dekens en sliep. Eén van die mannen zei : "Ge moogt blij zijn dat ge zoveel kinderen hebt, anders zouden we jou ook meenemen." Ja, dat was nog eens een geluk bij een ongeluk. ${ }^{90}$ In feite werd de vraag aan Klaas gesteld, maar was het Julia die hem te snel af was door zelf vlug "vier " te antwoorden ${ }^{91}$. "Een kind is gered geworden daar mijn vrouw het voor een van ons liet doorgaan. De burgemeester die het

${ }^{84}$ AG, Dossier Louis Debra, Uiteenzetting der feiten opgemaakt door substituut-krijgsauditeur Jan Maes, 1 december 1949.

${ }^{85}$ Ibid.

${ }^{86}$ Ibid.

${ }^{87}$ Ibid.

${ }^{88}$ Dora Eikelboom-Sluys gaf dit talliet op 9 september 2005 aan de auteur uit dank voor al het onderzoek. Dora zei hierover : "Ik dacht : "Hij vertelt erover. Hij kan het laten zien." En hij was er blij mee. ", Ten minste Sylvieke, PRO (Protestantse Omroep), 23 maart 2007, Canvas, 23.1523.40 .

${ }^{89}$ Dit dienstmeisje heette Leonie Oostvogels.

${ }^{90}$ DES, J. Schuyten, Van 31 januari 1943 tot juli 16 of 171944 (Getuigenis geschreven op vraag van familieleden in de Verenigde Staten), december 1995.

${ }^{91}$ AG, Dossier Louis Debra, Proces-verbaal van een verklaring van Klaas Sluys met betrekking tot de inval inzake het onderzoek tegen Debra, 14 september 1945. 
had kunnen weten, heeft niets gezegd. ${ }^{92}$ De 27-jarige Julia blijft achter met de zorg voor vier kleine kinderen, met haar man in de gevangenis, met een zaak zonder bedrijfsleider en met de verantwoordelijkheid voor nog een tiental elders verborgen Joden. Daarop verhuizen haar ouders naar Withof om Julia in deze zware tijden bij te staan en te helpen.

Uit wat we uit het vonnis van Sluys kunnen afleiden, blijkt dat Myriam en haar kinderen op 1 februari wellicht apart werden ondervraagd op het hoofdkwartier van de Sipo-SD in de Della Faillelaan 21 in Wilrijk. "In der Hauptverhandlung ist durch die Vernehmung des Angeklagten und die Verlesung der Aussagen von Alexander, Paula, Annie und Maria Gross vom 1.2.1943 - Bl. 3 und 4 d.A - sowie durch die uneidliche Vernehmung des Zeugen Krim. Ass. Käeding folgender Sachverhalt festgestellt worden : [...] (Laut Aussage einer der Kinder GROSS) hatte Angeklagte die Juden unterrichtet, dass sie bei einer Festnahme sagen sollten, sie waren erst den Abend vorher zu dem Angeklagten gekommen. [...] Er bestreitet nur den Juden gesagt zu haben, dass sie bei einer Revision die wirkliche Dauer Ihres Aufenthaltes verschweigen sollten. Er wird hier aber durch die protokollierten Erklärungen der Familie Gross überführt, welche die übereinstimmend angegeben hat. ${ }^{93} \mathrm{Op} 3 \mathrm{fe}-$ bruari worden zij, in afwachting van hun deportatie, overgebracht naar het Sammellager in de Kazerne Dossin te Mechelen ${ }^{94}$.

Nadel wordt overgebracht naar de gevangenis van Antwerpen. Tijdens zijn ondervragingen begin maart geeft hij niets prijs over diegenen die hem verborgen in het Stuyvenbergziekenhuis ${ }^{95}$. Nochtans weten zijn ondervragers dat hij pas kort vóór 31 januari bij Sluys is toegekomen ${ }^{96}$. Vermits Jeanne Schuyten nadien geen bezoek heeft gekregen van de Sipo-SD, kunnen we ervan uitgaan dat Nadel niemand heeft verraden. Na een maand in de gevangenis van Antwerpen, wordt hij op 5 maart overgebracht naar Mechelen ${ }^{97}$. Op 19 april wordt hij,

\footnotetext{
92 AG, Dossier Louis Debra, Getuigenis van Klaas Sluys op de openbare zitting van het proces van Debra, 8 december 1949.

93 MS, Feldkommandantur 520, St.L. VI nr.60/43, Vonnis van Klaas Sluys, 1 april 1943.

${ }^{94}$ E-mail van Laurence Schram (Kazerne Dossin) aan de auteur, 14 april 2005.

${ }^{95}$ DO, Dossier Hersz Nadel, Formulaire de Renseignements, 1958.

${ }^{96}$ MS, Feldkommandantur 520, St.L. VI nr.60/43, Vonnis van Klaas Sluys, 1 april 1943.

${ }^{97}$ DO, Dossier Hersz Nadel, Attest van de Administration des Dommages aux Personnes, 21 april 1958.
} 
net zoals Myriam Grosz en haar drie kinderen, met Judentransport XX gedeporteerd. Pas drie dagen later arriveert het transport in Auschwitz. Geen van hen keert levend terug 98 .

Sluys zegt na de oorlog dat hij eerst veertien dagen werd vastgehouden in de Della Faillelaan en er tweemaal door de Sipo-SD werd ondervraagd, alvorens te worden overgebracht naar de gevangenis in de Begijnenstraat te Antwerpen ${ }^{99}$. Op 24 februari 1943 wordt Sluys overgedragen aan de Feldkommandantur $520^{100}$. Het Feldgericht oordeelt op 1 april 1943 : «Der Angeklagte wird wegen Herstellung und Verbreitung von Flugschriften, Abhörens nichtdeutscher Sender und Verbotene Beherbergung von Juden zu eine Gesamtstrafe von zwei Jahren Zuchthaus verurteilt. ${ }^{101}$ Klaas had inderdaad zonder toelating, te vaak of in te grote oplage zijn reclametijdschrift Alchimist, het religieuze blad Vlaanderen voor Kristus en het eveneens religieuze pamflet Geen vrede zonder Christus gedrukt. Hij had inderdaad jarenlang regelmatig naar de Britse én vanaf 15 januari 1943 ook naar de Zwitserse radiozender geluisterd, en dat doorverteld aan zijn vrouw. Voor het eerste van deze "vergrijpen" geven de rechters Baudisch, Bethmann en Lühring hem vier in plaats van zes maanden, en voor het tweede acht maanden in plaats van één jaar en drie maanden. Verzachtende omstandigheden voor deze strafverminderingen zijn : «Es mag strafmildernd hier berücksichtigt werden, dass ein deutschfeindlicher Inhalt nicht festgestellt werden konnte und dass der Angeklagte nicht aus unlauteren Motiven gehandelt hat. [...] Bei diesen Strafen hat das Gericht durchaus berücksichtigt dass der Angeklagte 4 [sic] kleine Kinder hat. »102 Maar uit de motivering voor de straf voor het verbergen van Joden blijkt duidelijk dat de nationaal-socialist in Kriegsgerichtsrat Dr. Baudisch (en zijn bijzitters) niet in het minst onder de indruk is van de motieven die Klaas hiervoor opgeeft, namelijk dat hij : «als Christ aus Mitgefühl gehandelt habe. Er hatte es nicht über das Herz gebracht, die Juden dem Elend preis-

${ }^{98}$ W. Adriaens - E. Hautermann - I. Marquenie - P. Ramet - L. Schram - M. Steinberg, op. cit., deel 4, pp. 144, 275 en 308.

${ }^{99}$ Archief Heemkundige Kring van Boechout, Vragenlijst van het Belgische Commissariaat voor Repatriëring - Dienst voor Opzoeking en Identificatie - met medewerking van het Rode Kruis van België, sd (DO, Dossier Klaas Sluys).

${ }^{100}$ Ibid.

${ }^{101}$ MS, Feldkommandantur 520, St.L. VI nr.60/43, Vonnis van Klaas Sluys, 1 april 1943.

${ }^{102}$ Ibid. 
zugeben. $~^{103}$ Baudisch antwoordt daarop ijskoud : «A Auch die Beherbergung der Juden ist eine schwere Gesetzesverletzung. Der Angeklagte musste sich sagen, dass er die Juden nicht nur dadurch den notwendigen Verhaltungsmassnahmen entzog, sondern auch bei der bekannten Einstellung dieser Rasse die Sicherheit der Besetzungsmacht gefährdete, weil die Juden in dieser Verfassung zu allen möglichen Gesetzwiedrigkeiten, wie Spionage, Sabotage, und ähnlichen benutzt werden können. Das gilt insbesonders für den Juden Nadel, der dem Angeklagten gänzlich unbekannt war. Auch die angeblichen Beweggründe des Angeklagten können mildernd nicht ins Gewicht fallen. In harten Kriegszeiten ist für derartige Gefühle kein Raum, wenn sie sich so offensichtlich gegen sichtige Anordnungen der Besatzungsmacht richten. Deshalb hat das Feldkriegsgericht für die Beherbergung der Juden eine Gefängnisstrafe von einem Jahr als angemessene Sühne angesehen. $\aleph^{104}$

Tot 28 mei mag Julia hem om de andere week in de gevangenis in Antwerpen bezoeken ${ }^{105}$. Ergens tussen 17 maart en eind mei wordt Sluys eenmaal samen met Door Hendrickx in de gevangenis ondervraagd door Debra en Holm, die willen weten waar de tien Joden naar toe zijn die bij Door Hendrickx verborgen zaten en die juist op tijd hebben kunnen ontsnappen ${ }^{106}$. Op 28 mei wordt Sluys overgebracht naar de gevangenis van Sint-Gillis in Brussel. Van 8 juni tot 27 september kan Julia hem weer bezoeken, deze keer in de gevangenis van Leuven. Hij krijgt er een nierontsteking, en een dokter maakt hierover een rapport op. Op 22 september schrijft hij vlak voordat hij wordt overgeplaatst naar Kassel in Duitsland nog een bijzonder ontroerende en bemoedigende afscheidsbrief aan zijn echtgenote; een brief waarvan elke zin is doordrongen van zijn onwaarschijnlijk groot geloof en vertrouwen in een goede afloop ${ }^{107}$. Nadat Kassel zwaar was gebombardeerd, wordt Sluys tewerkgesteld in een vliegtuigfabriek in Nieder-

\footnotetext{
103 Ibid.

104 Ibid.

105 DES, J. Schuyten, Van 31 januari 1943 tot juli 16 of 171944 (Getuigenis geschreven op vraag van familieleden in de Verenigde Staten), december 1995.

${ }_{106}$ AG, Dossier Louis Debra, Getuigenverklaring van Door Hendrickx op het proces tegen Debra, 2 december 1949.

${ }^{107}$ MS, Brief van Klaas Sluys aan Julia Schuyten, 22 september 1943.
} 
Rhoden, in Schierstein en opnieuw Nieder-Rhoden ${ }^{108}$. Julia slaagt er naar eigen zeggen in om met de hulp van o.a. haar vriendin, de protestantse Margareta Verhelle, in contact te komen met een dame die op goede voet zou hebben gestaan met een hooggeplaatste Duitse rechter, die in ruil voor steekpenningen bereid was ervoor te zorgen dat Sluys uitstel van straf kon krijgen en hij op grond van het in Leuven opgemaakte medisch rapport omwille van "gezondheidsredenen" vervroegd kan vrijkomen ${ }^{109}$. Wat er ook van zij, op 28 juni 1944 wordt hij inderdaad van het gevangenenkamp te Rodgau overgebracht naar de gevangenis van Antwerpen om daar op 13 juli 1944 na acht maanden « zeer mager en zwak maar niet ziek» te worden vrijgelaten ${ }^{110}$. De kans is bijzonder groot dat Julia door deze démarche het leven van haar echtgenoot redt.

\section{De inval bij de Hendrickxen}

Nadat het echtpaar Hönig heeft ondergedoken gezeten bij René en Nelly, en na de aanhouding van Sluys enkele dagen heeft doorgebracht bij John Polderman en zijn vrouw, komen ook zij uiteindelijk terecht bij zuivelhandelaar Door Hendrickx en zijn vrouw Philomena Coenen, in de Drie Eikenstraat 59 te Edegem. Zij vervoegen er hun dochters Lily en Edith, Anna Kron-Hönig, Heinz Schindler, Markus en Laura Finkel en hun kinderen Gottfried en Selma. In maart 1943 verbergen ook hun zoon Charles Hendrickx en diens vrouw Yvonne Noë Joden in hun huis in de Lentelei 35 te Edegem ${ }^{111}$. Een schoonzus van Sigmund Hönig, de in november 1938 vanuit Wenen naar België gevluchte Rosl Gross-Berlstein, arriveert er wellicht ergens eind november of begin

\footnotetext{
${ }^{108}$ Archief Heemkundige Kring van Boechout, Vragenlijst van het Belgische Commissariaat voor Repatriëring - Dienst voor Opzoeking en Identificatie - met medewerking van het Rode Kruis van België, sd.

${ }^{109}$ DES, J. Schuyten, Van 31 januari 1943 tot juli 16 of 171944 (Getuigenis geschreven op vraag van familieleden in de Verenigde Staten), december 1995; e-mail van Henri Rooze, zoon van Margareta Verhelle, aan de auteur, 7 november 2008 ; AG, dossier Louis Debra, Getuigenis van Klaas Sluys op de openbare zitting van het proces van Debra, 8 december 1949.

${ }^{110}$ DO, Dossier Klaas Sluys, Attestation du Ministère de la Santé Publique et de la Famille, 4 mei 1965 ; DES, J. Schuyten, Van 31 januari 1943 tot juli 16 of 171944 (Getuigenis geschreven op vraag van familieleden in de Verenigde Staten), december 1995.

111 AG, Dossier Louis Debra, Proces-verbaal van het getuigenis van Charles Hendrickx op de openbare zitting van het proces van Debra, 2 december 1949.
} 
december 1942. Op 20 november 1942 haalt zij met haar rantsoenkaart nog een laatste keer aardappelen bij kleinhandelaar François Van Halen in Schaarbeek ${ }^{112}$. Op 11 maart 1943 komt ook haar man, Igo Gross, aan bij de paswerker Charles Hendrickx en zijn gezin met twee kleine meisjes, bij wie op dat ogenblik ook nog twee andere Joden verborgen zitten, namelijk de uit Amsterdam afkomstige doktersvrouw en doktersassistente Sophia Bremer-Bremer en haar twee jaar oud dochtertje Karin Bremer ${ }^{113}$. De uit Nederland afkomstige, vierentwintig jarige Joodse koopman Jonas Polak, die eerder ook al was ondergedoken bij Charles Hendrickx, en Bremer vertrouwen hun juwelen en waardepapieren toe aan de Vlaamse diamantkoopman Gustaaf De Schutter. «Zelfs heb ik Polak bijgestaan 8 maanden lang door juweelen voor hem te verkoopen en hem geld voor te schieten » aldus De Schutter ${ }^{114}$. Maar wat Polak niet weet, is dat De Schutter en zijn schoonzoon, Alfons Van den Heurck, ook bevriend zijn met de virulent antisemitische Debra $^{115}$. Als Polak en Bremer plannen om van onderduikadres te veranderen en naar het veiligere Brussel te verhuizen, vraagt Polak hiervoor aan De Schutter 60.000 Bfr. terug te geven ${ }^{116}$. De Schutter laat hem naar het huis van zijn schoonzoon in de Lange Leemstraat 32 te Antwerpen komen en maakt hem duidelijk dat hij ook met Bremer wil praten, naar eigen zeggen : « Over de schulden welk haar vader moest aan mij $~^{117}$. Hij overtuigt Polak hem naar het tot dan toe voor hem onbekende onderduikadres te brengen voor een onderhoud met Bremer. Een kwartier na hun aankomst bij Charles Hendrickx, vallen een gewapende en niet in uniform opererende Debra en een Duits lid van

\footnotetext{
112 Kazerne Dossin, Dossier Rosalie Berlstein, Rantsoeneeringskaart.

113 DV, Dossier Igo Gross, A318886, Proces-verbaal van de Schaarbeekse politie met betrekking tot zijn activiteiten tijdens de bezetting, 7 november 1944; AG, Dossier Louis Debra, Proces verbaal van het getuigenis van Jonas Polak, Door en Charles Hendrickx in de zaak tegen Gustaaf de Schutter en Ludovic Van den Heurck, 21 september 1944 ; e-mail van Frank Rooze, echtgenoot van Liliane Hendrickx, aan de auteur, 15 mei 2005 . Zie : http ://www.joodsmonument.nl/person/504247/nl. Het tweede oudste dochtertje, geboren in 1942, zou juist omwille van de ondergedoken Joden, op dat moment elders hebben verbleven (telefonisch gesprek van Greet Rooze met de auteur, 27 juli 2011).

114 AG, Dossier Louis Debra, Proces-verbaal van de verklaringen van Gustaaf De Schutter, 22 september 1944 .

115 AG, Dossier Louis Debra, Proces-verbaal van de verklaringen van Gustaaf De Schutter en Ludovicus Van den Heurck, 22 september 1944.

116 Ibid.

117 Ibid.
} 
de Sipo-SD in burger daar binnen, wellicht getipt door Alfons Van den Heurck ${ }^{118}$. Debra stormt naar boven en treft daar Polak, Bremer en De Schutter aan ${ }^{119}$. Op het moment dat Polak zijn vervalste identiteitskaart op naam van « De Poort » toont, wordt hij door Debra in het aangezicht geslagen, door De Schutter verraden en gearresteerd, samen met Bremer ${ }^{120}$. Als Charles zegt dat Sophia's dochtertje een kind is van hem en zijn echtgenote, trapt Debra erin. Debra en zijn kompaan arresteren ook nog Igo Gross. Op het moment dat de Duitser bij zijn huiszoeking de deur van het buitentoilet opentrekt, ziet hij daar de blonde Rosl Gross-Berlstein zitten, verontschuldigt hij zich, sluit onmiddellijk de deur en stapt terug naar binnen. Zo vlug als ze kan, maakt Rosalie zich uit de voeten. Ook Charles Hendrickx kan ontsnappen. Wanneer Debra en de Duitser met Gross, Polak en Bremer zijn vertrokken, verwittigt Charles onmiddellijk zijn vader, die daarop de tien Joden die bij hem verborgen zitten stante pede de straat opstuurt ${ }^{121}$. Deze zwerven rond tot zij 's avonds op goed geluk aankloppen bij een boer die hen terug in contact brengt met René Schuyten, die vanaf het moment dat Klaas is gearresteerd de coördinatie van het informele netwerk heeft overgenomen.

's Anderendaags, op 14 maart, komen Debra en de bijzonder hardvochtige en fanatieke Vlaamse Jodenjager en Dolmetscher bij de Antwerpse Sipo-SD, Felix Lauterborn, tot driemaal toe terug en vragen zij naar Charles. Op bevel van Debra wordt de kleine Karin Bremer alvast

118 AG, Dossier Louis Debra, Proces-verbaal van de verklaringen van Charles Hendrickx met betrekking tot de inval inzake het onderzoek tegen Debra, 25 augustus 1945 ; AG, Dossier Louis Debra, Proces-verbaal van het getuigenis van Charles Hendrickx op de openbare zitting van het proces van Debra, 2 december 1949.

119 AG, Dossier Louis Debra, Proces-verbaal van de verklaringen van Gustaaf De Schutter en Ludovicus Van den Heurck, 22 september 1944.

${ }^{120}$ Ibid. Na de oorlog proberen De Schutter en Van den Heurck zich vrij te pleiten van (vrijwel) alle schuld door te melden dat zij wisten waar de zus van Polak verborgen zat en dat zij haar niet verraden hebben. Van den Heurck zegt zelf : « Na de aanhouding van Polak ben ik nog in verbinding geweest met de zuster van Polak en dit verscheidene keren; nochtans heb ik haar nooit verontrust noch aangegeven en bleef ze uit de handen der Gestapo. Moest ik Polak hebben verraden dan was het natuurlijk voor mij ook gemakkelijk geweest zijn zuster te verraden. Zelfs heb ik hen gedurende een jaar geholpen om zich schuil te houden. Zij zelf kunnen ten mijne voordele hierin getuigen. " (AG, Dossier Louis Debra, Proces-verbaal van de verklaringen van Ludovicus Van den Heurck, 22 september 1944).

121 AG, Dossier Louis Debra, Proces-verbaal van de verklaringen van Charles Hendrickx met betrekking tot de inval inzake het onderzoek tegen Debra, 25 augustus 1945. 
meegenomen ${ }^{122}$. Vermoedelijk heeft haar moeder iets gelost bij haar ondervraging op het hoofdkwartier van de Sipo-SD in de Della Faillelaan in Wilrijk, maar volgens Debra is het « Polak geweest die gezegd heeft daar het kindje er nog was ${ }^{123}$. Op 15 maart komen ze weer en dreigen zij ermee om Yvonne op te pakken als Charles zich niet aangeeft $^{124}$. Op 17 maart geeft Charles zich aan ${ }^{125}$. Ook hij wordt naar de Della Faillelaan gebracht en daar voor een nacht opgesloten in de kelder ${ }^{126}$. Dezelfde dag vallen Debra en Lauterborn met getrokken revolver binnen bij Door Hendrickx, wat wordt bevestigd door Lauterborn zelf : « Ik beken deze feiten, ik was met Debra. »127 De tien Joden die hij en zijn vrouw verbergen, zijn dan al weg, maar Lauterborn zegt na zijn inspectie van de bovenverdieping tegen Door Hendrickx : "Precies dat er wel Joden geweest zijn. »128 Twee dagen later komen Debra en Lauterborn terug en arresteren zij alsnog Door en zijn vrouw ${ }^{129}$. Hun jongste zoon Eduard is die dag niet thuis omdat hij een uitnodiging heeft gekregen om op de Werbestelle te Antwerpen te komen ${ }^{130}$. Debra rijdt met Lauterborn, Hendrickx en diens vrouw naar de Werbestelle maar ze vinden de jongen niet. Daarop voeren ze het koppel naar de gevangenis ${ }^{131}$. Eduard wordt gewaarschuwd en keert niet terug naar huis. Tot aan de bevrijding verbergt hij zich bij René Schuyten en Nelly ${ }^{132}$. Wat er met de eveneens nog bij haar ouders inwonende zus

122 Ibid. AG, Dossier Louis Debra, Proces-verbaal van het getuigenis van Charles Hendrickx op de openbare zitting van het proces van Debra, 2 december 1949.

${ }^{123}$ Ibid.

124 Ibid.

125 AG, Dossier Louis Debra, Proces-verbaal van de verklaringen van Charles Hendrickx met betrekking tot de inval inzake het onderzoek tegen Debra, 25 augustus 1945.

126 AG, Dossier Louis Debra, Proces-verbaal van het getuigenis van Charles Hendrickx op de openbare zitting van het proces van Debra, 2 december 1949.

${ }_{127}$ AG, Dossier Louis Debra, Uittreksel uit het proces-verbaal van de verklaring van Charles Hendrickx en de confrontatie met Lauterborn, 25 augustus 1945.

${ }_{128}$ AG, Dossier Louis Debra, Proces-verbaal van het getuigenis van Door Hendrickx op de openbare zitting van het proces van Debra, 2 december 1949; AG, Dossier Louis Debra, Procesverbaal van het getuigenis van Philomena Coenen op de openbare zitting van het proces van Debra, 2 december 1949.

${ }^{129}$ Ibid.

130 AG, Dossier Louis Debra, Proces-verbaal van het getuigenis van Door Hendrickx op de openbare zitting van het proces van Debra, 2 december 1949.

131 AG, Dossier Louis Debra, Proces-verbaal van het getuigenis van Philomena Coenen op de openbare zitting van het proces van Debra, 2 december 1949.

${ }^{132}$ MHS, Handgeschreven presentatie van Nelly Opstelten voor Paul Hickman, haar kleinzoon, zijn Duitse les, 12 april 1994. 
Angèle is gebeurd, is ons niet bekend. Ze wordt in ieder geval niet aangehouden ${ }^{133}$.

Alle redders en slachtoffers worden op het hoofdkwartier van de $\mathrm{Si}$ po-SD ondervraagd door de brutale Judenreferent Kriminaloberassistent SS-Oberscharführer Erich Holm, en door Debra, door Hilfspolizeibeamte Emiel Janssens, die Belgen opspoorde die Joden verborgen hielden of verborgen hadden, en door nog een blonde man ${ }^{134}$. Sommigen worden met elkaar geconfronteerd, meer dan eens ondervraagd en geslagen door Holm, maar tevergeefs ${ }^{135}$. Debra moet vermoedens gehad hebben over mogelijke banden tussen Sluys en Hendrickx. Door Hendrickx getuigt : "Sluys is met mij geconfronteerd geweest op het verhoor... Wanneer Sluys met mij geconfronteerd is geworden was Debra er ook. »136 De Hönigs, de Finkels, Heinz Schindler, René en Nelly worden niet verraden. Charles Hendrickx wordt door de Feldkommandantur 520 te Antwerpen veroordeeld tot tien maanden gevangenis en Door Hendrickx tot een jaar voor het verbergen van Joden ${ }^{137}$. Eerst worden zij opgesloten in de gevangenis van Sint-Gillis en nadien in

${ }^{133}$ AG, Dossier Louis Debra, Proces-verbaal van de verklaring van Debra inzake de aanhouding van Joden te Edegem Lentelei en van de familie Hendrickx te Edegem inzake het proces van Debra, 9 november 1947.

134 AG, Dossier Louis Debra, Proces-verbaal van het getuigenis van Charles Hendrickx op de openbare zitting van het proces van Debra, 2 december 1949; AG, Dossier Louis Debra, Procesverbaal van de verklaringen van Debra met betrekking tot het op vraag van de onderzoeksrechter Beeckmans door hem opgesteld document met inlichtingen over medewerkers van de SD, GFP, Feldgendarmerie en Abwehr te Antwerpen, 11 september 1944.

135 AG, Dossier Louis Debra, Proces-verbaal van het getuigenis van Charles Hendrickx op de openbare zitting van het proces van Debra, 2 december 1949. AG, Dossier Louis Debra, Procesverbaal van het getuigenis van Door Hendrickx op de openbare zitting van het proces van Debra, 2 december 1949.

136 Ibid.; dit werd ook bevestigd door Sluys en door Philomena Coenen, die eveneens aanwezig was bij die confrontatie. AG, Dossier Louis Debra, Proces-verbaal van het getuigenis van Klaas Sluys op de openbare zitting van het proces van Debra, 2 december 1949. AG, Dossier Louis Debra, Proces-verbaal van het getuigenis van Philomena Coenen op de openbare zitting van het proces van Debra, 2 december 1949.

137 Tijdens het proces van Debra zegt Door Hendrickx dat hij werd veroordeeld tot 18 maanden gevangenis voor het verbergen van joden. AG, Dossier Louis Debra, Proces-verbaal van het getuigenis van Door Hendrickx op de openbare zitting van het proces van Debra, 2 december 1949. Dat wordt verklaard door het feit dat hij op het moment van zijn veroordeling al zes maanden in voorarrest heeft gezeten; AG, Dossier Louis Debra, Proces-verbaal van de klacht die Door Hendrickx neerlegt tegen Debra wegens verklikking aan den vijand en diefstal, 23 september 1944 ; DO, Dossier Hendrickx, Jacobus D. Isidorus, Inlichtingsblad, 23 juli 1952. 
Merksplas ${ }^{138}$. Op 22 november 1943 worden zij, mogelijks wegens overbevolking van de gevangenis, naar Frankrijk overgebracht naar de bouwplaatsen van de Atlantikwall, Oberbauleitung Nord-Ouest van de Organisation Todt. Dit gebeurt opvallend genoeg drie weken nadat de Militärverwaltung in België 1230 Joodse dwangarbeiders uit België, die sinds de zomer van 1942 werkten in dezelfde bouwplaatsen in Noord-Frankrijk, heeft overgeleverd aan de Sipo-SD zodat die haar quota van gedeporteerde Joden kan halen, en hen op transport zet naar Muizen bij Mechelen, van waaruit het $X V I^{e}$ en het XVII ${ }^{\mathrm{e}}$ transport worden samengesteld richting Auschwitz ${ }^{139}$. Blijkbaar is er daardoor een tekort aan arbeidskrachten ontstaan. Op 2 december slagen beiden erin om te ontsnappen, naar België terug te keren en onder te duiken tot aan de dag van de bevrijding in hun geboorteplaats Geel ${ }^{140}$. Philomena Coenen, de vrouw van Door, werd op 3 september 1943, na zes maanden in voorarrest in de gevangenis van Antwerpen, zonder proces vrijgelaten ${ }^{141}$.

Op 19 april 1943 worden Sophia en Karin Bremer, Jonas Polak en Igo Gross met de respectievelijke nummers 1236, 1237, 1235 en 1265 gedeporteerd naar Auschwitz met het bekende Judentransport $X X^{142}$. Sophia en Karin overleven het niet, maar Polak en Gross, die misschien in dezelfde wagon zaten, slagen erin om in de buurt van Tienen via een klein raampje uit de trein te springen ${ }^{143}$. Gross keert terug naar

138 AG, Dossier Louis Debra, Proces-verbaal van het getuigenis van Charles Hendrickx op de openbare zitting van het proces van Debra, 2 december 1949.

${ }^{139}$ DO, Dossier Hendrickx (Charles) Maria Carolus Josephus, Fiche van de Duitse Afdeling van de Rijksweldadigheidskolonie te Merksplas, 22 november 1943. W. Adriaens - E. Hautermann I. Marquenie - P. Ramet - L. Schram - M. Steinberg, op.cit., deel 1, p. 262.

140 Telefonisch gesprek van Liliane Hendrickx, dochter van Charles, met de auteur, 15 mei 2005.

${ }^{141}$ AG, Dossier Louis Debra, Proces-verbaal van de klacht die Door Hendrickx neerlegt tegen Debra wegens verklikking aan den vijand en diefstal, 23 september 1944; DO, Dossier Coenen Philomena, Formulier van onderzoek van het Ministerie van het Algemeen Bestuur en der Pensioenen, 18 september 1950.

142 W. Adriaens - E. Hautermann - I. Marquenie - P. Ramet - L. Schram - M. Steinberg, op. cit. deel 4, pp. $52,143,295$.

143 E-mail van Edith Hönig aan de auteur, 27 april 2005 ; AG, Dossier Louis Debra, Procesverbaal van het getuigenis van Jonas Polak, Door en Charles Hendrickx in de zaak tegen Gustaaf de Schutter en Ludovic Van den Heurck, 21 september 1944. Deze getuigenverklaring was ook het bewijs dat, in tegenstelling tot wat eerder werd aangenomen, Polak niet was omgekomen in Auschwitz, maar dat hij van het $\mathrm{XX}^{\mathrm{e}}$ transport is gesprongen. Ook bevestigd door Charles Hendrickx : « Ik heb later vernomen dat Gross en Polak uit de transport trein gesprongen zijn en ontsnapt zijn. Ik heb ze nadien trouwens gezien. » (AG, Dossier Louis Debra, Proces-verbaal van het getuigenis van Charles Hendrickx op de openbare zitting van het proces van Debra, 2 
zijn verblijfplaats op de Haechtsesteenweg 406 te Schaarbeek, waar zijn oude buren hem weten te vertellen waar zijn vrouw zich intussen heeft verborgen. Zo slaagt hij erin om zijn vrouw Rosl, de Hönigs, de Finkels en Heinz Schindler te vervoegen ${ }^{144}$. Heinz is er inmiddels in geslaagd om een aan zijn tante Julia Herzfeld-Felderbaum verwante tandarts in het Brusselse te contacteren ${ }^{145}$. Deze Otto Hutterer, die als kwart-Jood tijdens de oorlog nooit verontrust wordt en zelfs kan blijven verder werken, is de schoonbroer van Julia Felderbaum, en met zijn hulp kunnen ze op 1 april 1943 eerst terecht in Hutterers liefdesnest in de Landbouwersstraat 41 te Etterbeek bij zijn minnares, mevrouw Van Hée, alvorens vanaf 8 april tot aan de bevrijding terecht te kunnen in een huurappartement op de eerste verdieping in de Hoevestraat 53 in Sint-Joost-ten-Noode ${ }^{146}$. Eerst vijf dagen later arriveren daar ook Sigmund Hönig en zijn vrouw ${ }^{147}$. Gottfried Finkel en Lily Hönig duiken eerst nog onder in de Fonteinstraat 85 te Hasselt, alvorens pas op 11 september 1943 de rest van de groep te vervoegen ${ }^{148}$. Hutterer zorgt ervoor dat een Belgisch koppel, een zekere mevrouw Hermans en haar vriend Louis, cipier in een Brusselse gevangenis, het pand kunnen huren, er kunnen wonen op het gelijkvloers en tegelijk kunnen instaan voor de aanvoer van voedsel - dat vooral bestaat uit aardappelen - en andere levensbehoeften van de twaalf Joden die zich schuilhouden op de andere verdiepingen ${ }^{149}$. Het koppel wordt voor zijn

december 1949; DV, Dossier Gross, Israel, A318886, Proces-verbaal van de politie van Schaerbeek naar aanleiding van een Enquête relative à l'activité des étrangers Gross, Israël et Berlstein Rosalie, pendant l'occupation allemande, 7 november 1944).

144 Ibid.

145 Julia Herzfeld-Felderbaum had zelf in augustus 1942 een onderduikadres gevonden bij Gustave en Maria Allegretto-Van Trappen in de François Delcoignestraat 26 te Koekelberg. Zij bleef daar tot 1 juni 1945. (E-mail van George Herzfeld, zoon van Julia Herzfeld-Felderbaum, aan de auteur, 1 april 2007 ; e-mail van Edith Hönig aan de auteur, 3 november 2008).

${ }^{146}$ DV, Dossier Schindler, Heinz, 2014544, Rapport van de politie van Sint-Joost-ten-Noode, 10 november 1944; E-mail van George Herzfeld, zoon van Julia Herzfeld-Felderbaum, aan de auteur, 1 april 2007. Hutterer had toen een vriendin, en na de oorlog is zijn vrouw, Trude Michel, van hem gescheiden. Zij hadden geen kinderen (E-mail van Edith Hönig aan de auteur, 3 november 2011).

${ }^{147}$ DV, Dossier Hönig, Sigmund, A213361, Politierapport van de stad Brussel, 2 december 1944.

${ }^{148}$ DV, Dossier Gottfried Finkel, A280367, Verslag van de politie van de $7^{\mathrm{e}}$ wijk in Antwerpen opgemaakt op vraag van de Openbare Veiligheid met betrekking tot de houding van Finkel tijdens de bezetting, 16 augustus 1946; DV, Dossier Lily Hönig, A213361, Inlichtingsbulletijn betreffende vreemdelingen, 14 februari 1947.

149 E-mail van Edith Hönig aan de auteur, 23 mei 2005. 
aanwezigheid aldaar en voor het bezorgen van de nodige levensmiddelen maandelijks betaald door Sigmund Hönig150. Op het moment dat Hönig door zijn geldreserves heen zit, kan hij rekenen op de ruime financiële hulp van Julia (en Klaas), die hem een enorme som geld voorschiet om de onkosten voor het onderduiken te kunnen dekken ${ }^{151}$. Gedurende bijna anderhalf jaar verlaat niemand van de Joden het pand. In die tussentijd zorgen Hutterers assistente, Lilian Willem, en andere niet-Joodse helpers voor de dagelijkse voedselbevoorrading en voor de noodzakelijke communicatie ${ }^{152}$. Brussel wordt bevrijd op 4 september 1944. Kort daarop melden zij zich om zich te laten inschrijven in het vreemdelingenregister ${ }^{153}$. Allen overleven de oorlog. Op vraag van en voorgedragen door Edith Hönig worden in 1997 Klaas Sluys (postuum) en Julia Schuyten door Yad Vashem erkend als Righteous Among the Nations ${ }^{154}$.

Sylvieke noodgedwongen overgebracht naar de Roozes in KorbeekLo

In mei 1943 vangt Jeanne Schuyten van op haar bureau in het ziekenhuis een conversatie op tussen bezoekers bij een zieke. Julia getuigt : « Ze hoorde vertellen dat ze in Boechout Meneer Sluys hadden komen halen omdat er Joden in huis waren en ze vertelden : "Ze hebben nog een Joods meisje in huis, dat hebben ze niet meegenomen". Jeanne belde me dat en zei : "Zorg dat Silvieke ergens anders kan worden ondergebracht." Nu woonde er in Leuven een familie Rooze die ons vroeger reeds geschreven had: als we soms iemand hadden waar we geen plek voor vonden dat zij ook wel wilde helpen (dat waren fijne christenmensen) ${ }^{155}$. Een neef van hen was een vriend van ons, Toine

\footnotetext{
${ }^{150}$ E-mail van Edith Hönig aan de auteur, 4 juli 2011.

151 DES, De balansen van 1944 en 1945 van Industrie \& Handelsmaatschappij Boechout, 31 december 1944 en 31 december 1945

152 E-mail van George Herzfeld aan de auteur, 30 mei 2007.

153 DV, Dossier Hönig, Sigmund, A213361, Inschrijving in het vreemdelingenregister, 11 september 1944; DV, Dossier Schindler, Heinz, 2014544, Inschrijving in het vreemdelingenregister, 11 september 1944 .

$154 \mathrm{http}: / /$ wwwl.yadvashem.org/yv/en/righteous/pdf/virtial_wall/belgium.pdf; Yad Vashem, Dossier Sluys, Klaas en Schuyten, Juliana, M31.2/7578.

${ }^{155}$ Henri Rooze en Truus van Buuren waren zoals de meeste andere redders en helpers lid van de Gereformeerde Kerk.
} 
Rooze, en die heeft dan Silvieke naar dat gezin in Leuven gebracht. Daar was ze veilig. $»^{156}$

De ochtend van 11 mei 1943 speelt er zich een hartverscheurend tafereel af in de keuken van Withof ${ }^{157}$. Er klopt iemand op de deur en als Julia opendoet staat daar een voor Sylvieke vreemde man voor de deur die ze nog nooit eerder heeft gezien. Julia, van wie Sylvieke denkt dat het haar moeder is, tilt het drie-en-een-half jaar oude meisje op, houdt haar stevig in haar armen en begint te huilen ${ }^{158}$. Sylvieke vraagt haar wat er mis is en zegt dat ze moet stoppen met huilen, waarop Julia van haar hart een steen maakt, Sylvieke in de armen van Toine Rooze duwt - die zelf nog maar vier dagen ervoor voor het eerst vader is geworden - en zegt : « Ga met hem mee! " $^{159}$ Rekening houdend met de voor Sylvieke traumatiserende ervaring om van Julia te worden gescheiden, houdt de emotionele toestand waarin Sylvieke verkeert voor Toine een groot risico in ${ }^{160}$. Toch slaagt Toine erin om Sylvieke over te brengen naar de burgerlijk ingenieur Henri Rooze en de gewezen onderwijzeres Truus van Buuren, een jong gezin met drie kleine kinderen, wonende op de Tiensesteenweg 207 te Korbeek-Lo, nabij Leuven ${ }^{161}$.

\footnotetext{
156 J. Schuyten, Van 31 januari 1943 tot juli 16 of 171944 (Getuigenis geschreven op vraag van familieleden in de Verenigde Staten), december 1995. Het verhaal wordt bevestigd door de oudste dochter, Dora Sluys. Ten minste Sylvieke, PRO (Protestantse Omroep), 23 maart 2007, Canvas, 23.15-23.40.

${ }^{157}$ DV, Dossier Reichman, Benjamin, 1379678, Inlichtingsbulletijn betreffende vreemdelingen, 9 september 1944. Het formulier van de gemeente Korbeek-Lo, dat nota bene ondertekend is door G.W.V. Rooze-van Buuren met de handgeschreven vermelding «Persoon die de vluchteling herbergt » geeft 11 mei 1943 op als de datum van haar aankomst in de gemeente.

${ }^{158}$ Visual History Foundation, Survivors of the Shoah, Interview 27861 met Sylvie Lednicer, 2 april 1997. Sylvie heeft al die tijd gedacht dat dat haar moeder was. Het is pas door de confrontatie met de data dat ze zich realiseerde dat het hier om Julia moest gaan (Gesprek van Sylvie Lednicer-Reichman met de auteur, 11 september 2005). En toen later Sylvie het aanrecht en de keuken beschreef, bevestigde Dora Sluys dat dat de keuken van Withof was, wat Sylvie deed concluderen dat de herinneringen van kleine kinderen erg vervormd kunnen zijn (Getuigenis van Sylvie Lednicer-Reichman, in Ten minste Sylvieke, PRO, 23 maart 2007, Canvas, 23.15-23.40).

159 Ibid. ; e-mail van Sylvie Reichman aan de auteur, 2 februari 2006 ; Herbert Rooze werd geboren op 7 mei 1943 (Brief van Greet Rooze, dochter van Toine Rooze, aan de auteur, 14 juli 2006).

${ }^{160} \mathrm{~S}$. Oliner \& P. Oliner, De altrü̈stische persoonlijkheid. Waarom riskeerden gewone mannen en vrouwen hun leven om anderen te redden?, Amsterdam, 1989, p. 80.

161 Sylvie besloot om de Yad Vashemmedaille aan te vragen voor Henri Rooze en Truus Van Buuren (http ://wwwl.yadvashem.org/yv/en/righteous/pdf/virtial_wall/belgium.pdf) Heel wat informatie over dit gezin is afkomstig uit het dossier dat de kinderen Rooze opmaakten voor Yad Vashem (Yad Vashem, Dossier Rooze, Henri en van Buuren, Geertruida, M31.2/10920; e-mail
} 
Op dat ogenblik houden zij al van in 1942 een Joods meisje verborgen, achtjarige Josephine van Engel afkomstig uit de Burgemeester Tellegenstraat 60 te Amsterdam. Aan de kinderen Rooze wordt zij voorgesteld als hun nichtje ${ }^{162}$. Haar vader, de diamantslijper Jacob van Engel, is reeds bij het begin van de oorlog krijgsgevangen gemaakt ${ }^{163}$. Haar moeder, de gewezen diamantkliefster, Keetje van Loggem, heeft eind juni 1942 haar vijf maanden oud dochtertje Clara achtergelaten bij vrienden, die een gemengd huwelijk hebben ${ }^{164}$. Samen met Josephine heeft zij geprobeerd om naar Zwitserland te vluchten, maar strandt zij uiteindelijk in Antwerpen, waar zij op 2 maart 1944 wordt opgepakt en opgesloten in de gevangenis ${ }^{165}$. Maar gelukkig is het Joods Verdedigingscomité, het Joods verzet, er reeds in 1942 in geslaagd om Josephine te plaatsen bij de Roozes ${ }^{166}$.

Als een echte "religious-moral rescuer" is de ruimhartige Truus bereid om in de loop van 1944 tot aan de bevrijding nog zes andere Joden te verbergen ${ }^{167}$. Op 1 februari 1944 arriveert de eveneens uit Amsterdam afkomstige, 22-jarige Sofie Vlessing, op 26 april 1944 gevolgd door het kinderloze echtpaar Wesley uit Maastricht en tenslotte, in de zomer van 1944, nog twee kinderen, een zekere Leo en Adèle, en hun oom. Joop Rooze meent dat zij van een transport zijn gesprongen. «'s Avonds liepen de gevluchte Joden langs de huizen, waar ze dan aanbelden om onderdak te vragen. Zo zijn Leo en Adèle met een oom bij ons komen aanbellen en mijn moeder heeft hen toen onderdak verschaft. De volgende dag vertelde de buurvrouw wat haar was overkomen : ontsnapte Joden hadden aangebeld om onderdak te vragen en ze

van Nannie Beekman (Yad Vashem) aan de auteur, 6 juli 2011 ; e-mail van Joop Rooze aan de auteur, 7 april 2006).

${ }_{162}$ Er was ook in het echt een nichtje dat Willemien heette (e-mail van Joop Rooze aan de auteur, 22 oktober 2005)

163 E-mail van Jacques Huisman, weduwnaar van Josephine van Engel, aan de auteur, 28 oktober 2008.

${ }^{164}$ Clara noemt zich nu Carla. Brief van Carla Nikkelsburg-van Engel aan de auteur, 22 november 2008.

165 Jacob van Engel sterft vlak na de bevrijding van Bergen-Belsen aan dysenterie. Keetje van Loggem wordt nooit op transport gezet en overleeft de oorlog (Ibid).

166 Het Ondergedoken Kind, Fiche originale du fichier des "enfants cachés" constitué par le Comité de Défense des Juifs concernant Madame Van Engel, Joséphine, 2279 : « Pour subvenir aux besoins de ces enfants, le C.D.J. faisait parvenir argent, timbres et cartes de ravitaillement. » Brief van Jacques Funkleder (Het Ondergedoken Kind) aan de auteur, 30 maart 2006.

${ }^{167}$ E. Fogelman, op.cit., p. 163. 
zei dat ze dat niet gedaan had. Tevens vroeg ze mijn moeder of zij bij zo'n vraag wel onderdak zou verlenen. Mijn moeder antwoordde haar dat zij dat zeker niet kon doen omdat ze kleine kinderen in huis had en dat dan niet verantwoord was. $\mathrm{Zij}$ was opgelucht dat de buurvrouw haar niet "verdacht". »" ${ }^{168}$ De twee kinderen staan wel op een groepsfoto die genomen is op 5 september 1944, naar aanleiding van de bevrijding ${ }^{169}$. Hun ware identiteit konden we voorlopig nog niet achterhalen.

Uit veiligheidsredenen wordt Josephine "Willemien" genoemd, Sylvieke wordt "zusje" en Sofie wordt "tante Fie". Of ook de namen "Leo" en "Adèle" schuilnamen zijn, konden we tot op heden niet achterhalen. Zij worden in ieder geval voorgesteld als een neefje en een nichtje ${ }^{170}$. Alle acht Joden verblijven tot aan de bevrijding op 5 september 1944 bij Henri en Truus en hun eigen vier kinderen - Jaap werd geboren op 30 mei 1944 -, een huishouden vormend van maar liefst veertien personen.

Maar voor de bevrijding beleven zij nog enkele bange momenten. Begin 1944 krijgt Sofie te horen dat negen maand ervoor haar ouders werden opgepakt ${ }^{171}$. Vanaf april 1944 tot aan de bevrijding is het daar bij momenten akelig spannend met zware bombardementen op 26 april, 1 mei, 12 en 13 mei, en 25 mei. Leuven is immers een belangrijk knooppunt van spoorwegen. Ze horen eveneens dat op 4 juni Annie, de zus van Truus, in Nederland door de Duitsers werd opgepakt. Als lid van het Nederlandse verzet hielp zij geallieerde piloten wier vliegtuig was neergeschoten terug naar Engeland te krijgen. Op 4 augustus wordt zij naar het kamp in Vught overgebracht ${ }^{172}$. Eind juni krijgen ze volledig onverwacht bezoek van de Feldgendarmen; gelukkig alleen in verband met een verduisteringskwestie, omdat de ramen onvoldoende

168 E-mail van Joop Rooze aan de auteur, 21 juli 2005. Voorlopig kon deze informatie nog niet worden bevestigd, maar als die klopt, dan zou het moeten gaan om Judentransport XXVI met 563 personen, waaronder 47 kinderen, dat op 31 juli 1944 uit Mechelen was vertrokken (S. Klarsfeld en M. Steinberg, Memoriaal van de deportatie der Joden uit België, Brussel - New York, 1982 , repr. 1994, p. 36).

${ }^{169}$ Archief Joop Rooze (JR) : foto genomen voor het huis van de Roozes, 5 september 1944.

${ }^{170}$ E-mail van Joop Rooze aan de auteur, 18 juli 2005.

171 JR, Dagboekaantekeningen van Truus Rooze-Van Buuren, 31 december 1944. David Vlessing en Rebecca Paur zullen op 9 juli 1943 in Sobibor aankomen. Zij overleven het niet (http ://www.joodsmonument.nl/page/394690).

172 JR, Dagboekaantekeningen van Truus Rooze-Van Buuren, 31 december 1944. Zij zal nog naar het concentratiekamp van Ravensbrück worden overgebracht waar zij zal blijven tot mei 1945 (email van Joop Rooze aan de auteur, 2 november 2008). 
zijn verduisterd. Tenslotte zijn er voorafgaand aan de bevrijding ook nog heel zware gevechten in de omgeving van en rond hun huis ${ }^{173}$. Die bevrijding komt blijkbaar niets te vroeg. Volgens Joop Rooze stond zijn vader op een lijst van 200 personen die kort daarna zouden worden opgepakt en geëxecuteerd ${ }^{174}$. Deze lijst zou volgens Henri Rooze vernietigd zijn geworden door Wehrkreiskommandeur Major Dr. Reinold von Thadden-Trieglaff, een protestantse dominee die dankzij zijn gematigd optreden in Leuven heel wat respect van de bevolking genoot $^{175}$.

Ook hier maakt de sociale isolatie van deze protestanten de zaken wat gemakkelijker. "Voor de buren was het Nederlandse familie die bij ons logeerde, omdat er onvoldoende eten was in Nederland. Na de oorlog zeiden de buren dat ze wel wisten dat het geen familie was, maar onderduikers. ${ }^{176}$ Hun overburen en tevens goede vrienden, het echtpaar Dewilde, neemt Truus wel in vertrouwen. Het is ook dit echtpaar dat hen actief helpt. De kinderen mogen telkens als het mooi weer is, gaan spelen in de 50 ha grote tuin van de Bunswyck, het kasteel waarin het echtpaar Dewilde tijdens de oorlog mocht wonen ${ }^{177}$. En Joop Rooze vult aan : "Van Mijnheer O[swald] Dewilde, de echtgenoot van mevr. Dewilde, kregen wij extra voedselbonnen. Hij werkte als landbouwingenieur op de hoeve van de zusters in Lovenjoul. Die zusters verzorgden zieken, die extra bonnen kregen vanwege hun ziekte. De zusters hielden veel bonnen over en mijnheer Dewilde had deze aan de zusters gevraagd voor ons gezin. In de zomer 1944 hadden wij

173 JR, Dagboekaantekeningen van Truus Rooze-Van Buuren, 31 december 1944.

${ }^{174}$ E-mail van Joop Rooze aan de auteur, 17 april 2007.

175 « Reinold von Thadden was een Duitse dominee. Hij heeft veel gedaan voor de Leuvense bevolking en is nadien door het Leuvens stadsbestuur tot ere-burger van Leuven benoemd. In het begin van de jaren '50 gaf von Thadden een lezing in Brussel in de Franstalige protestantse kerk in de Belliardstraat en mijn vader is daar naartoe geweest. Daar vertelde hij mijn vader dat von Thadden zelf ook op het eind verdacht werd nadat hij een lijst van 200 namen die opgepakt en geëxecuteerd moesten worden, heeft vernietigd. » (e-mail van Joop Rooze aan de auteur, 17 april 2007). Ook een artikel in The Times maakt hiervan melding. Obituary. Dr Reinold von ThaddenTrieglaff. Noted German Evangelist, in The Times, 11 oktober 1976. Hij werd echter nooit ere burger van Leuven en ook het weigeren van een bevel om gijzelaars te executeren, wordt door de voormalige Leuvense burgemeester Smets in twijfel getrokken (Stadsarchief Leuven, Brief van burgemeester A. Smets aan de directie van The Times, 3 november 1976).

${ }_{176}$ E-mail van Joop Rooze aan de auteur, 13 mei 2005.

177 http://www.kasteeldebunswyck.be/Feestzaal-Seminaries-Leuven.htm ; getuigenis van Lie Dewilde in Ten minste Sylvieke, PRO (Protestantse Omroep), 23 maart 2007, Canvas, 23.1523.40 . 
verder een grote moestuin met heel veel groenten (vooral bonen) die mijn vader kweekte. Hij vertelde nadien steeds van de overvloedige oogst prinsessenbonen en hoe deze van pas kwamen om alle monden te voeden. » $^{178}$

Zeker vanaf de bevrijding krijgen de Roozes ook $750 \mathrm{Bfr}$. financiële steun per maand van het Aide aux Israélites Victimes de la Guerre (AIVG), de naoorlogse voortzetting van het Joods Verdedigingscomité (Comité de Défense des Juifs - JVC), voor Sylvie Reichman ${ }^{179}$. Vermits haar grootmoeder haar handen vol heeft aan het verzorgen van haar schoonzoon Eisig Safir, die Auschwitz overleefde, en tevens aan het zorgen voor diens dochters van dertien en vijf, vraagt Dobe GrunspanThaler of Sylvieke nog een tijd bij de Roozes mag blijven ${ }^{180}$. Zij blijft er uiteindelijk tot eind mei 1945181. Tot dan krijgen de Roozes maandelijks dit soort "kindergeld" uitbetaald. Of de Roozes dit kindergeld ook ontvingen voor Josephine en voor Sylvieke tijdens de bezetting is voorlopig niet duidelijk.

Behalve met het echtpaar Dewilde hebben de Roozes enkel contact met hun familie en met andere leden van de Protestantse Kerk. Hun zoon Joop denkt zelfs dat er nooit bezoek kwam, behalve dan dat van dominee Winter uit Antwerpen, die dominee was van de Gereformeerde Gemeente in de Sanderusstraat, waar ook Henri en Margriet Schuyten, Klaas en Julia Sluys, René en Nelly Schuyten, Toine Rooze en nog een aantal anderen bij zijn aangesloten. Winter staat zelf bekend als een hevige antinazi. Hij wordt er door de Sipo-SD ook van verdacht Joden te verbergen, waarop men hem ook laat bespioneren ${ }^{182}$. Hij blijkt inderdaad Joden te hebben verborgen, maar dat wordt nooit

${ }^{178}$ E-mail van Joop Rooze aan de auteur, 22 oktober 2005.

${ }^{179} \mathrm{DV}$, Fiche van het JVC-CDJ-AIVG met op de achterzijde de gedane betalingen, nr. 2280, 25 oktober 1944. « De AIVG gaf sociale hulp aan joodse slachtoffers van de oorlog. Zij werd hierin financieel hoofdzakelijk gesteund door het American Jewish Joint Distribution Committee (de Joint) » in V. Vanden Daelen, Laten we hun lied verder zingen. De heropbouw van de joodse gemeenschap in Antwerpen na de Tweede Wereldoorlog (1944-1960), Amsterdam, 2008, p. 371.

${ }^{180}$ E-mails van Sylvie Reichman aan de auteur, 29 mei 2005, 2 februari 2006, 20 april 2007 ; DV, Dossier Karfiol, Danuta, 2091923, Brief van het HISO aan de Administratie van de Vreemdelingenpolitie met betrekking de visa-aanvraag van Diana Karfiol en Henryk Diamant, een nicht van Sylvieke en haar echtgenoot, 14 juni 1946.

${ }^{181} \mathrm{DV}$, Fiche van het JVC-CDJ met op de achterzijde de gedane betalingen, nr. 2280, 25 oktober 1944.

${ }_{182}$ AG, Dossier Wyndaele, Emile, Proces-verbaal van de verklaring van dominee Herman Jan Winter, 11 november 1945. 
ontdekt ${ }^{183}$. Wellicht is hij door zijn duidelijke stellingname een goed rolmodel voor zijn gemeenteleden. Wie ook op de hoogte zijn van het feit dat de Roozes Joden verbergen, zijn dominee D.C. van Lonkhuizen en zijn vrouw. Tijdens de oorlogsjaren is hij predikant in de Gereformeerde Kerk te Mechelen. Hij, zijn vrouw en hun zoontje staan op een foto met de Roozes, Sylvieke en Josephine, en die foto is genomen in de zomer van 1944 wanneer het gezin van Lonkhuizen speciaal naar Korbeek-Lo komt om de doop van Jaap Rooze thuis te doen ${ }^{184}$. Joop Rooze bevestigt dit: «De familie Lonkhuizen zal zeker geweten hebben dat wij Joodse mensen in huis hadden. " ${ }^{185}$ Natuurlijk is het praktisch onmogelijk om in oorlogstijd met drie of vier kinderen bij anderen op bezoek te gaan. Daar komt trouwens bij dat volgens haar oudste zoon, Han Rooze, Truus als Nederlandse en als protestantse sowieso werd beschouwd als een buitenstaander, net zoals Klaas Sluys. Daarenboven was haar echtgenoot ook niet erg communicatief ${ }^{186}$. Los van hun isolatie wordt de redding ook vergemakkelijkt door affectieve gevoelens voor sommige Joden, al zijn die niet noodzakelijk doorslaggevend. Zo houden zowel Julia als Truus oprecht veel van Sylvieke. Maar zelfs die "moederliefde" weerhoudt Truus er niet van Sylvieke toch terug te geven aan haar eigen familie, ondanks het feit dat Sylviekes ouders niet terugkomen en het meisje zelf haar derde "moeder" in zes jaar niet wil verlaten ${ }^{187}$.

\section{Slot}

In 1947 emigreren Sylvieke en haar grootmoeder naar de Verenigde Staten waar ze wordt geadopteerd door haar oom en tante langs moederszijde, Lobl Lachter en Charlotte Grunspan, die al in 1938 vanuit België naar de VS uitweken ${ }^{188}$. Grootmoeder Dobe sterft in 1948 in New York ${ }^{189}$. Het contact met Sylviekes redders geraakt verbroken. In

\footnotetext{
${ }^{183}$ E-mail van Marius Rooze, echtgenoot van Rina Blokland, aan de auteur, 6 april 2007.

${ }^{184}$ Archief Sylvie Lednicer-Reichman: foto genomen in de zomer van 1944.

${ }^{185}$ Ook Lies werd in 1942 thuis gedoopt (e-mail van Joop Rooze aan de auteur, 18 juli 2011).

${ }^{186}$ E-mail van Joop Rooze aan de auteur, 17 april 2007 : Joop heeft in deze mail antwoorden van

Han, Lies en zichzelf op vragen van de auteur geïntegreerd in één document.

${ }^{187}$ E-mail van Sylvie Reichman aan de auteur, 2 februari 2006.

${ }^{188}$ E-mail van Sylvie Reichman aan de auteur, 4 juli 2005.

${ }^{189}$ E-mail van Sylvie Reichman aan de auteur, 17 juli 2005.
} 
2005 vind ik haar met de hulp van Michlean Amir en Steven Vitto van het Registry of Holocaust Survivors van het U.S. Holocaust Memorial Museum (USHMM) in Washington terug in New York, en breng haar na zestig jaar weer in contact met kinderen van Klaas en Julia Sluys en met de kinderen van Henri en Truus Rooze ${ }^{190}$. Als rechtstreeks gevolg daarvan, worden in 2006 Henri en Truus op vraag van Sylvie, en ondersteund met bewijsstukken uit ons onderzoek, aangevuld met een uitvoerig getuigenis van de kinderen Rooze, door Yad Vashem (postuum) erkend als Righteous Among the Nations ${ }^{191}$.

Vijftien protestantse helpers en redders uit Antwerpen, Boechout, Edegem en Korbeek-Lo, die voor kortere of langere tijd tenminste 29 Joden hebben verborgen, van wie er 22 nog in leven zijn op het moment van de bevrijding, konden worden geïdentificeerd, evenals tien van de veertien daders die rechtstreeks betrokken waren bij de aanhouding of ondervraging van vier helpers en redders en van negen slachtoffers ${ }^{192}$. Sommige van de protestanten onder hen kunnen beschouwd worden als "paid helpers" die Joden verborgen uit winstbejag, maar vier anderen werden ook door Yad Vashem erkend als Righteous Gentiles, twee van hen als een rechtstreeks gevolg van dit onderzoek.

${ }^{190}$ E-mail van Steven Vitto (USHMM) aan de auteur, 27 mei 2005.

${ }^{191}$ http ://wwwl.yadvashem.org/yv/en/righteous/pdf/virtial_wall/belgium.pdf

192 Klaas en Julia Sluys (Boechout), Jeanne Schuyten (Antwerpen), Henri en Margriet Schuyten (Antwerpen), René en Nelly Schuyten (Edegem), Door en Philomena Hendrickx (Edegem), Charles en Yvonne Hendrickx (Edegem), John en Lea Polderman (?), Henri en Truus Rooze (Korbeek-Lo) redden Edith Hönig, Sigmund en Rosa Hönig, Igo en Rosl Gross, Anna KronHönig, Lily Hönig en Gottfried Finkel, Markus en Laura Finkel, Selma Finkel en Heinz Schindler, Jonas Polak (springt van de trein), Sylvie(ke) Reichman, Dobe Grunspan-Thaler, Josephine van Engel, Sofie Vlessing, het echtpaar Wesley, "Leo, Adèle en hun oom". Werden opgepakt en overleefden het niet: Myriam Grosz-Reichman en haar drie kinderen Paula, Alexander en Annie, Hersz Nadel, Sophia en Karin Bremer. Daders: de Duitsers Conrad Kaeding, Jan Pitz en Erich Holm, de Vlamingen Willy Wyndaele, Jan Schuermans, Louis Debra, Gustaaf de Schutter, Felix Lauterborn, Emiel Janssens. Twee Vlaamse leden van de Antwerpse Sipo-SD die bij de inval bij Sluys waren betrokken, konden niet worden geïdentificeerd, evenals de Duitser betrokken bij de inval bij Charles Hendrickx, en de blonde ondervrager. De loutere aanwezigheid van de Boechoutse oorlogsburgemeester Staf Van Sintjan bij de inval bij Sluys maakt hem volgens Klaas Sluys nog niet tot een dader. 


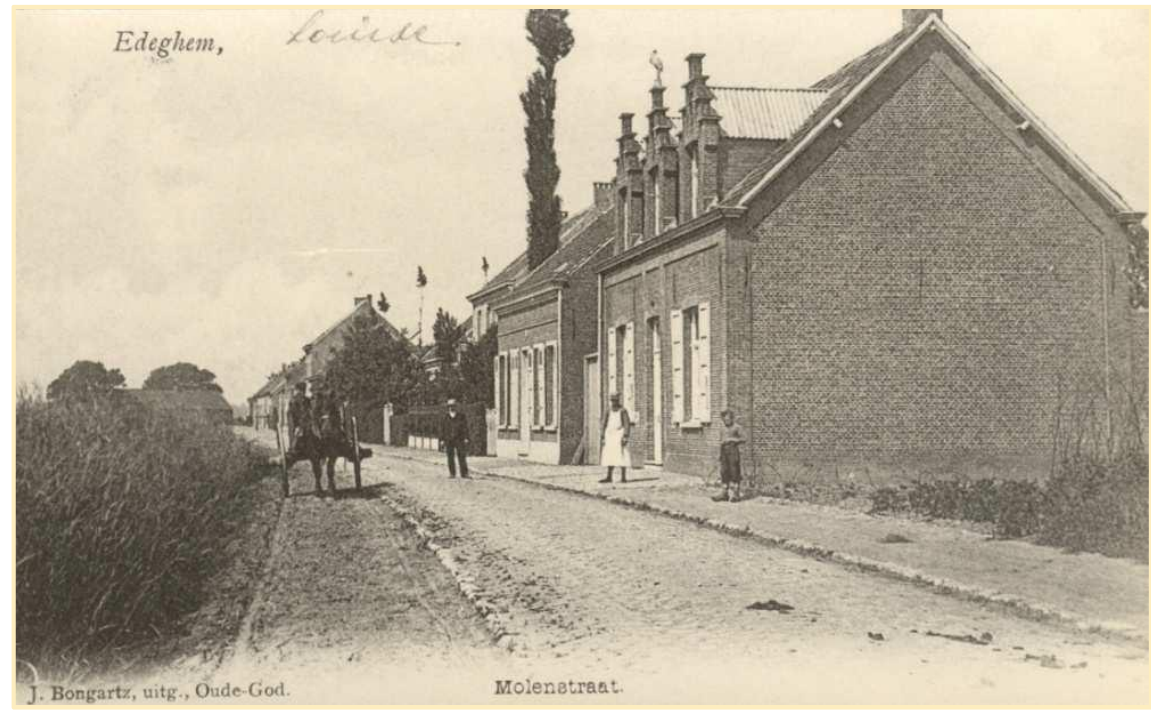

Drie Eikenstraat (voorheen Molenstraat) 59 te Edegem. 


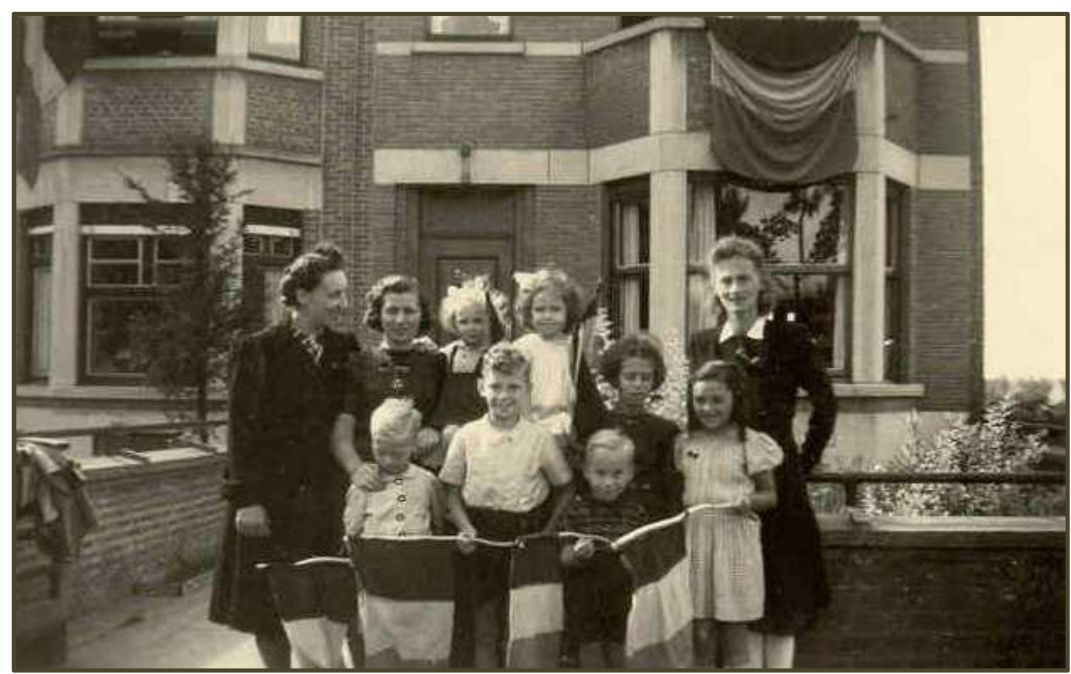

5 september 1944.

Van links naar rechts, achterste rij : Lie Dewilde, Sofie Vlessing, Lies Rooze, Sylvieke, Josephine van Engel, "Adèle", Truus Rooze. Voorste rij: Han Rooze, "Leo", Joop Rooze.

Familie Rooze met Sylvie Reichman en Josephine van Engel, zomer 1943.

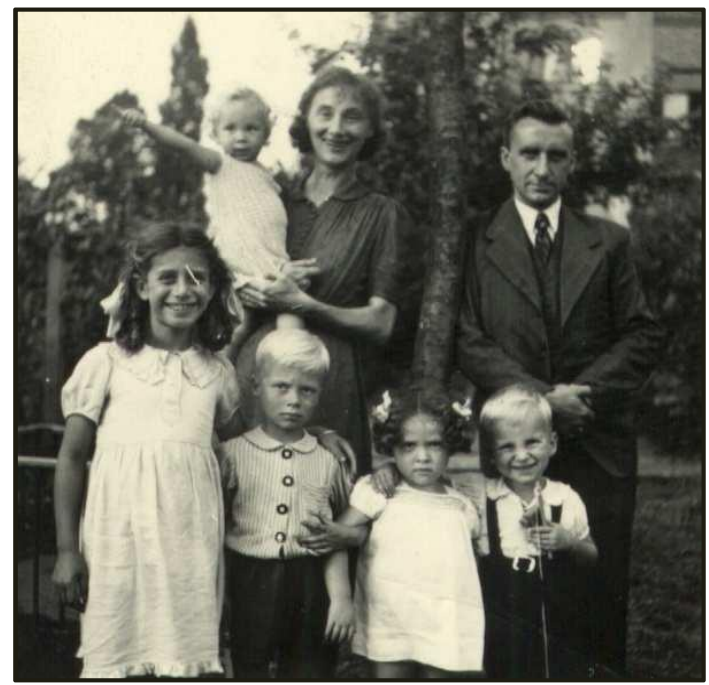




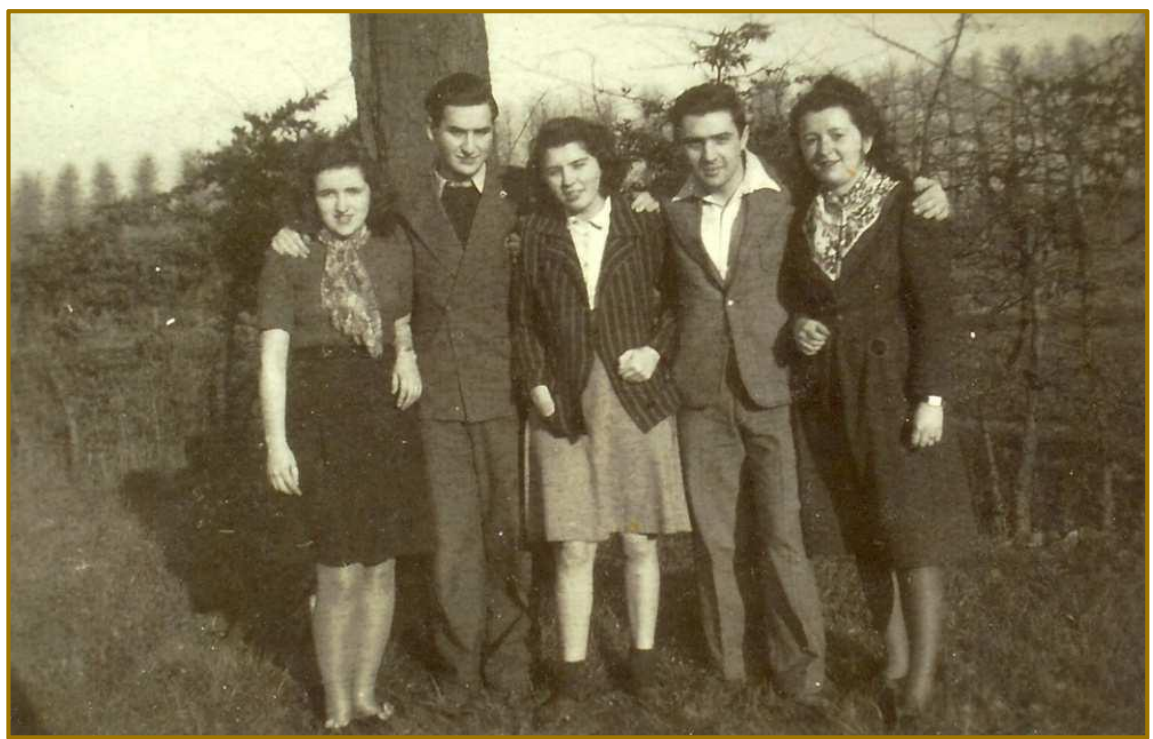

In de tuin van Door Hendrickx, begin 1943. Van links naar rechts : Edith IIönig, Heinz Schindler, Selma Finkel, Gottfried Finkel, Lily IIönig.

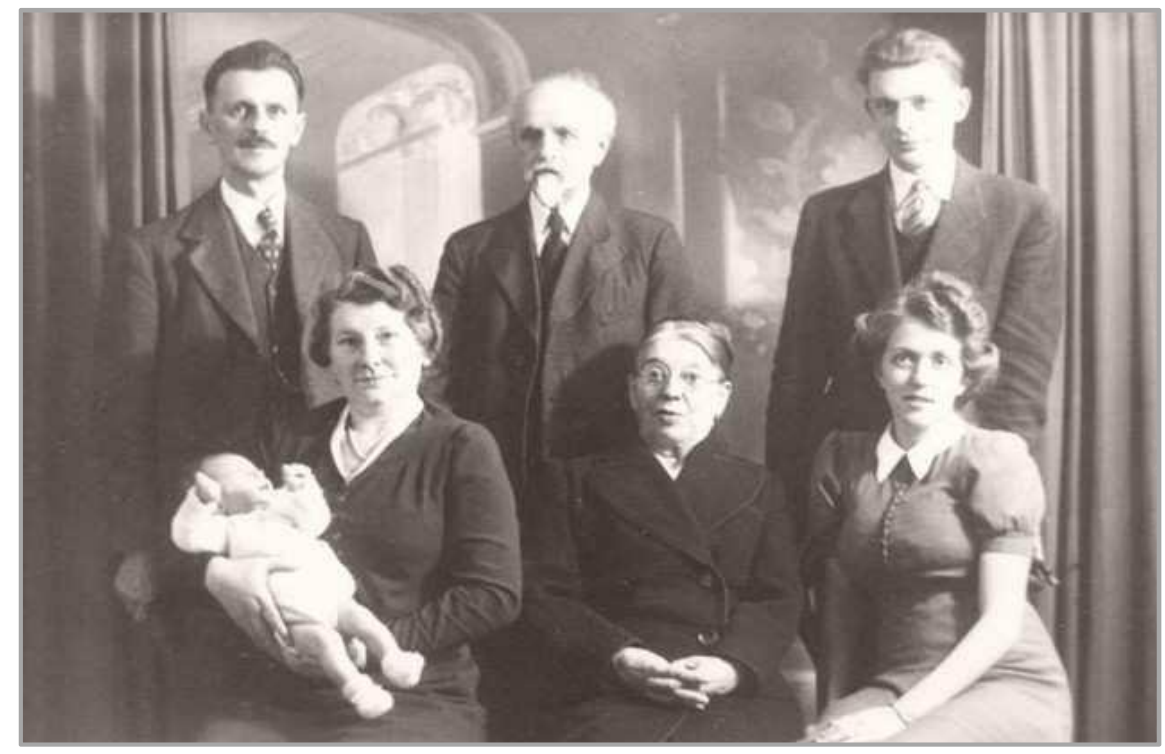

Henri \& Margriet, Médard \& Josephine, René \& Nelly en Peterke, oktober 1943. 

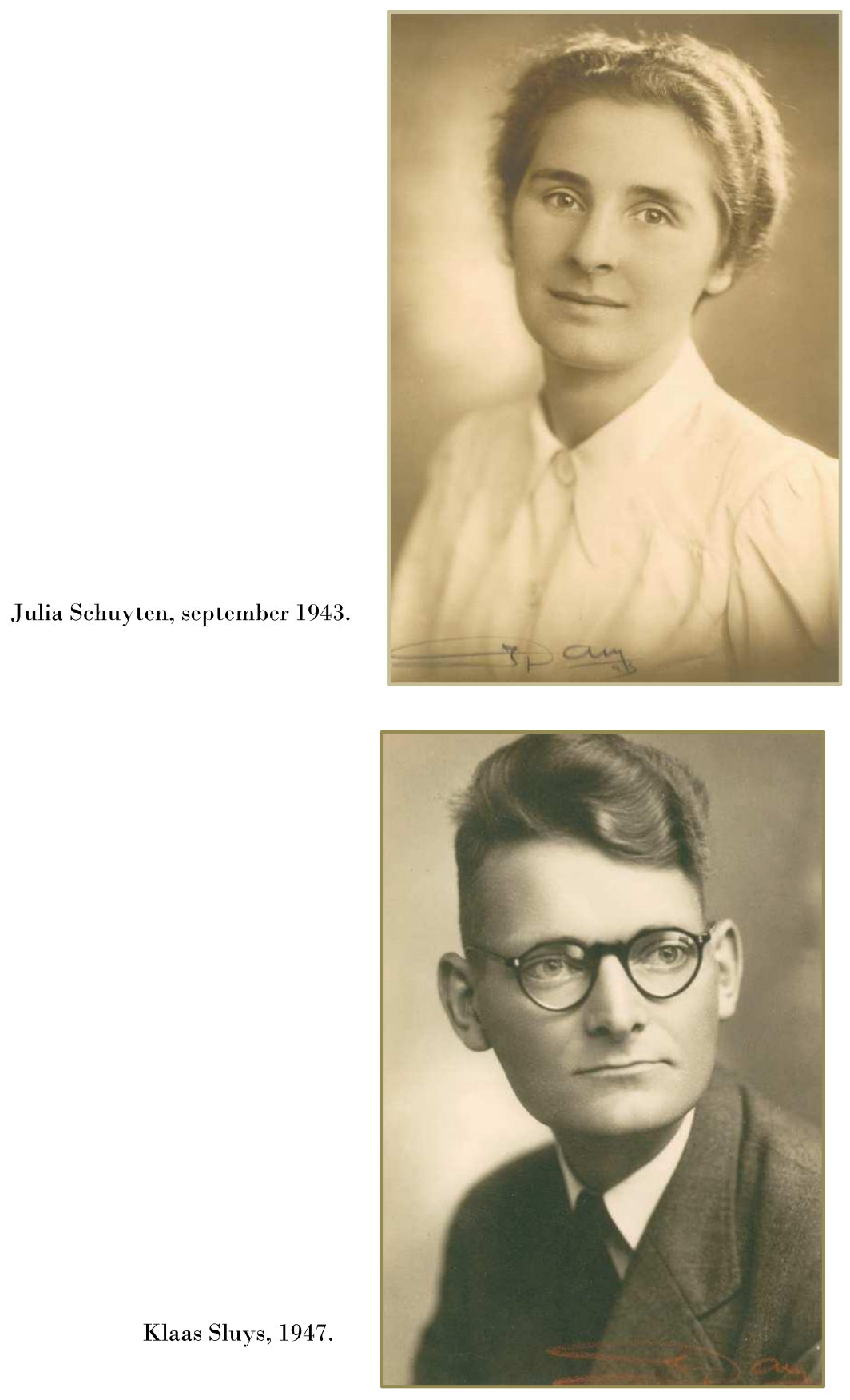

316 


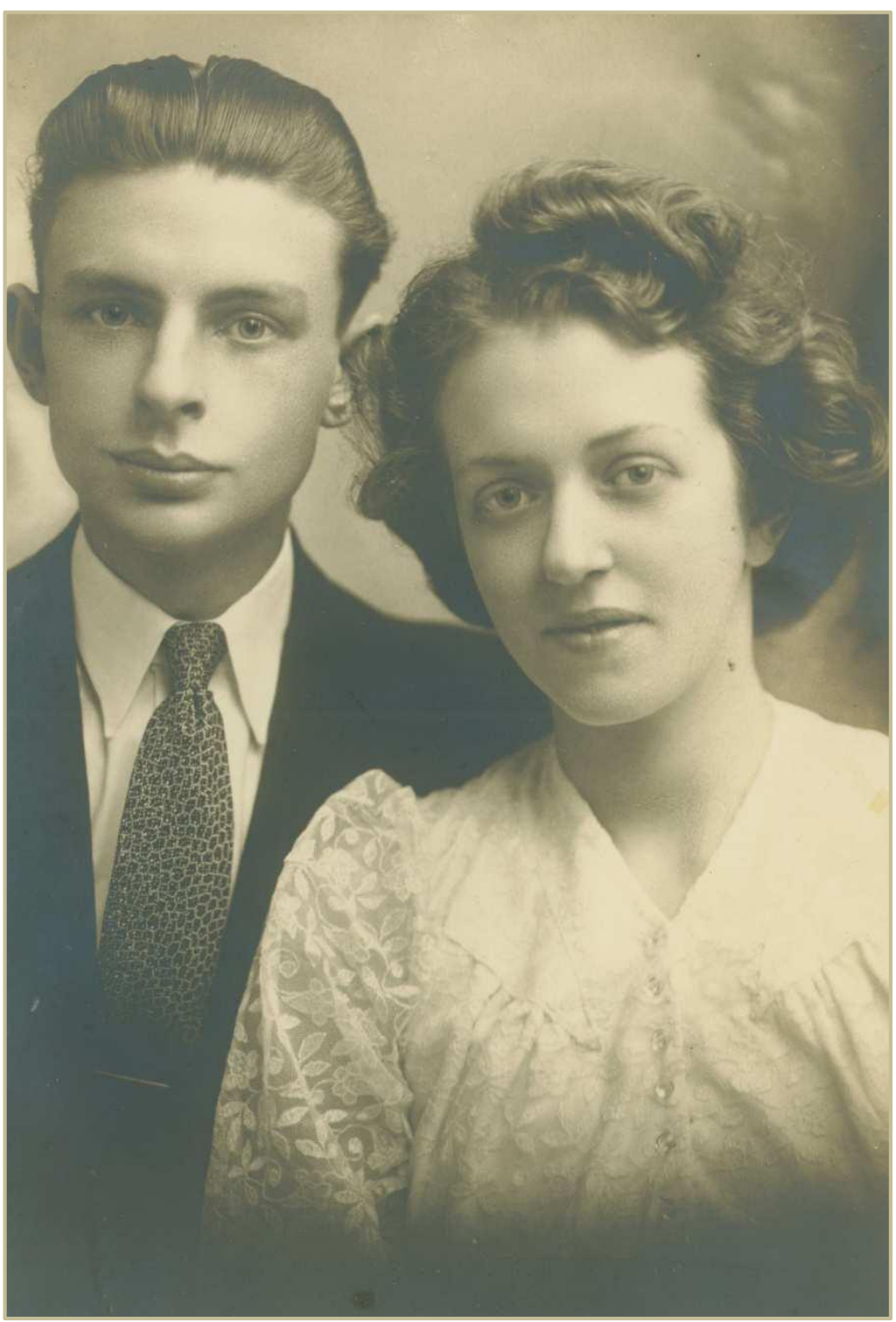

René en Nelly Schuyten op hun trouwdag, november 1942. 